\title{
FISSION TRACK GEOCHRONOLOGY OF THE NORTH ALEUTIAN COST \#1 WELL (OCS-8218), BRISTOL BAY BASIN, ALASKA
}

\author{
by \\ Steven C. Bergman ${ }^{1}$, John Murphy², and Shari Kelley ${ }^{3}$
}

\begin{abstract}
Zircon and apatite fission-track analyses were performed on six core samples of Eocene to Miocene sedimentary and volcaniclastic rocks from depths of 1,280-5,090 m in the North Aleutian COST \#1 well (NAC), Bristol Bay Basin, Alaska, for the purpose of constraining their thermal history and depositional provenance. Most apatite and zircon populations are complex and reflect mixtures of several age components based on $\mathrm{chi}^{2}$ statistics. Most samples exhibit older zircon fission-track ages than their corresponding apatite fission-track ages, except for two samples at present temperatures $\left(\mathrm{T}_{\mathrm{P}}\right)$ within the apatite partial annealing zone that paradoxically show the opposite relationship.

For the five samples shallower than $3,382 \mathrm{~m}$ at $\mathrm{T}_{\mathrm{p}}=38-104^{\circ} \mathrm{C}$, mean and peak apatite fission-track ages (30-74 Ma) are older than depositional ages (15-43 Ma) and mean track lengths range from 12 to $13 \mu \mathrm{m}$, together indicating that these samples have resided in the fission-track stability zone since deposition $\left(\mathrm{T}<60-90^{\circ} \mathrm{C}\right)$, although a detrital age component would allow partial resetting of the fission-track clock. The deepest sample, from $4,736 \mathrm{~m}$ depth $\left(\mathrm{T}_{\mathrm{P}}=144^{\circ} \mathrm{C}\right)$, displays a nearly totally reset apatite fission-track age of $9 \pm 2$ Ma with a mean track length of $9 \mu \mathrm{m}$, indicating it currently resides at temperatures within the apatite fission-track partial annealing zone $\left(>90-120^{\circ} \mathrm{C}\right)$; the fission-track age and track length distribution reflect significant post-depositional annealing, yet not total annealing, reflecting residence at temperatures below $130-140^{\circ} \mathrm{C}$ for geologic time periods. Although apatite compositions are not available for this sample, we predict they may be enriched in chlorine and hydroxyl $(\mathrm{Cl}-\mathrm{OH})$ and depleted in fluorine $(\mathrm{F})$ anions compared with the Durango apatite standard. Apatite uranium (U) contents show similar depth trends as the zircons where the younger, shallower samples exhibit higher uranium contents, and the deeper samples contain the lowest uranium contents. These apatite and zircon uranium-depth trends indicate a progressive unroofing of an evolving magmatic arc terrane with the deepest samples representing the primitive source magmatic rocks (uranium-depleted) and the shallowest samples representing more evolved magmatic rocks (uranium-enriched).

Corrected estimates of equilibrium bottom-hole temperatures, combined with inferred lithologydependent thermal conductivities, indicate a present-day day heat flow of $56 \mathrm{~mW} / \mathrm{m}^{2}$, corresponding to a mean geothermal gradient of $31^{\circ} \mathrm{C} / \mathrm{km}$ for the section. Both the vitrinite and apatite fission-track data are consistent with a simple Tertiary burial history and a paleo-heat flow similar to or below current values, indicating the stratigraphic section encountered in the North Aleutian COST \#1 well has not experienced higher burial temperatures in the past. The apatite fission-track data indicate minimal erosion has occurred in the penetrated section and that the present-day temperatures have only recently been achieved.
\end{abstract}

\section{INTRODUCTION}

This report presents an analysis and interpretation of zircon and apatite fission-track data from the North Aleutian COST\#1 (NAC) well. The NAC well is situated north of the Aleutian Peninsula in the Bristol Bay Basin (fig. 1). Previous fission-track analyses were performed on wells from the Lower Cook Inlet Basin (synthesized in Murphy and Clough, 1999), but the authors are not aware of any having been reported on wells in the Bristol Bay Basin. The purpose of the present study is to constrain the provenance, depositional age, and thermal history of Cenozoic strata encountered in the NAC well. Logging temperatures and vitrinite reflectance data are integrated to independently derive a geohistory-based

thermal history model within which to interpret the fission-track data. Apatite and zircon fission-track closure temperatures depend on anion and cation composition and cooling rate (for example, Green and others, 1989; Gallagher and others, 1998) with proposed ranges of apatite between 110 and $140^{\circ} \mathrm{C}$, and zircon between 200 and $275^{\circ} \mathrm{C}$.

\section{REGIONAL GEOLOGIC SETTING AND STRATIGRAPHIC OVERVIEW}

The Bristol Bay Basin is located in a back-arc tectonic setting, bounded to the south by the Alaska Peninsula and associated active volcanic arc, approximately

13111 Quenby Avenue, Houston, Texas 77005

${ }^{2} 4687$ Amherst Drive, Fairbanks, Alaska 99709

${ }^{3}$ New Mexico State University, P.O. Box 30001, Las Cruces, New Mexico 88003-8001 
$350 \mathrm{~km}$ north of the Aleutian megatrench, the active plate boundary in which the Pacific plate is being subducted beneath the North American plate at $6.2 \mathrm{~cm} / \mathrm{yr}$ with an azimuth of $344^{\circ}$ (DeMets and others, 1994). The Bristol Bay Basin (figs. 1, 2) is one of several Cenozoic sedimentary basins that formed on the southern margin of the Bering shelf following a subduction zone jump that occurred at approximately 50-60 Ma (Detterman and others, 1969; Scholl and others, 1986; 1987; Finzel and others, 2005). A variety of tectonic models have been proposed for the Bristol Bay Basin, including subsidence caused by varying degrees of right lateral strike-slip faulting (for example, Worrall, 1991), back-arc extension, and flexural loading of the volcanic arc (Bond and others, 1988; Walker and others, 2003). The latter workers proposed that the Bristol Bay Basin formed by right lateral strike-slip faulting that induced early or middle Eocene extension, and late Eocene to middle Miocene flexural subsidence, and a late Miocene-Holocene flexural subsidence related to renewed volcanism on the Alaska Peninsula and a northward prograding deltaic system.
According to Parker and Newman (1995) and Finzel and others (2005), the main Bristol Bay Basin petroleum plays involve Oligocene and Miocene drapes over basement highs, although no regionally extensive seal units have been identified previously. Reservoir potential in the Oligocene and Miocene rocks in the NAC well at depths $<2,900 \mathrm{~m}$ are considered good to excellent, especially in the Tolstoi, Bear Lake, Unga, and Milky River Formations. Porosity and permeability are observed to increase and the degree of consolidation decrease up section. Onshore reservoir quality is generally poor due to the volcanogenic provenance, but the Miocene Bear Lake Formation possesses promising quality. Regional source rocks (mainly gas prone) have been recognized in Paleocene to Miocene age coals and nonmarine shales of the Tolstoi, Stepovak, and Bear Lake Formations. The organic material encountered in the NAC well is mainly type III, humic, gas-prone kerogen. The top of the oil window for hydrocarbon generation was estimated at $3,870 \mathrm{~m}$; the base was projected to be $6,100 \mathrm{~m}$. The main structural traps are thought to be primarily simple anticlines and slightly faulted anticlines. Projected resource means are 0.22 billion barrels oil and 6.7 TCF gas.

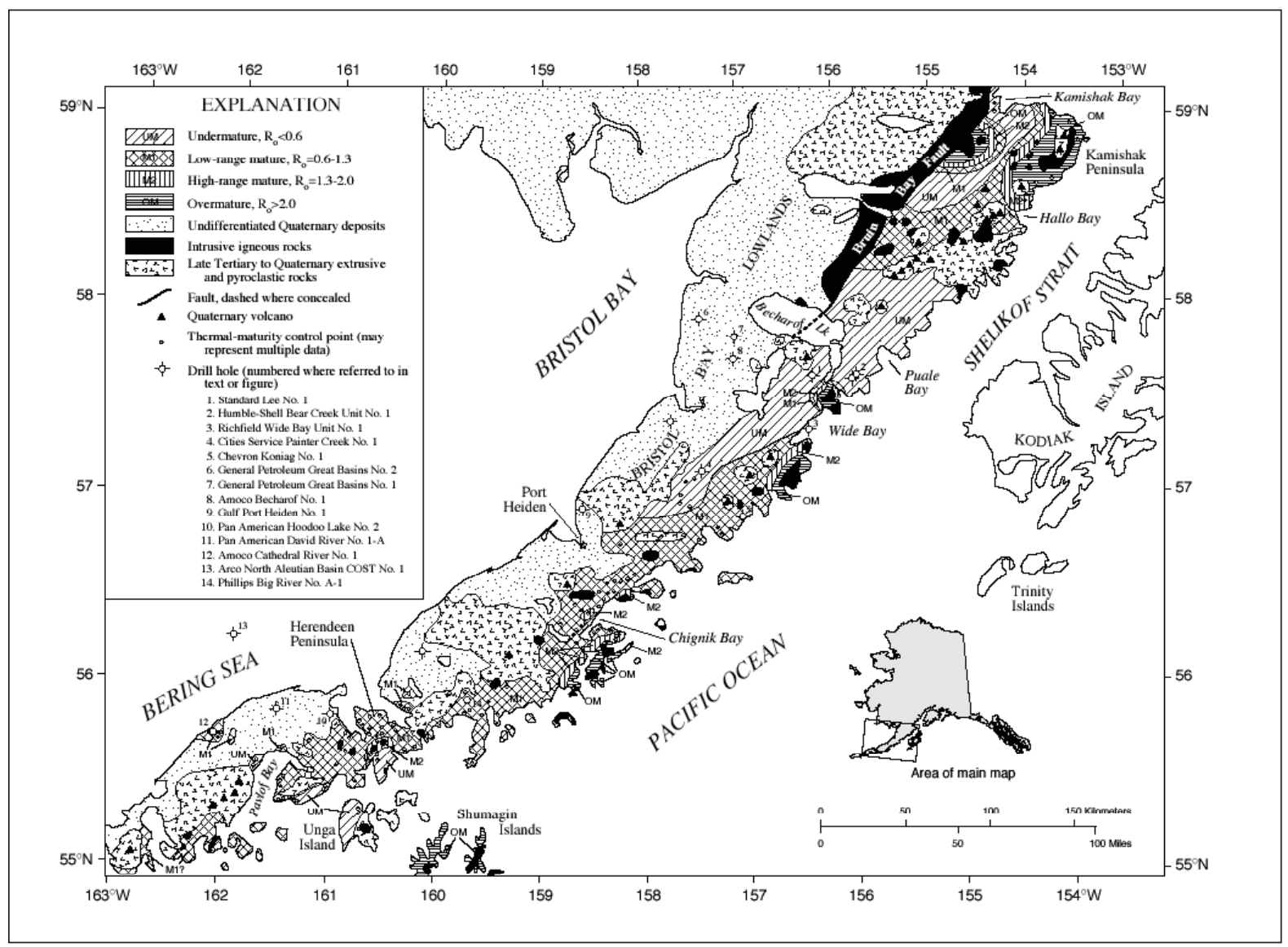

Figure 1a. Map of the Alaska Peninsula and Bristol Bay showing the location of the North Aleutian COST \#1 well (13), as well as distribution of Cenozoic igneous rocks and areas of anomalous thermal maturities; from Molenaar (1996). 


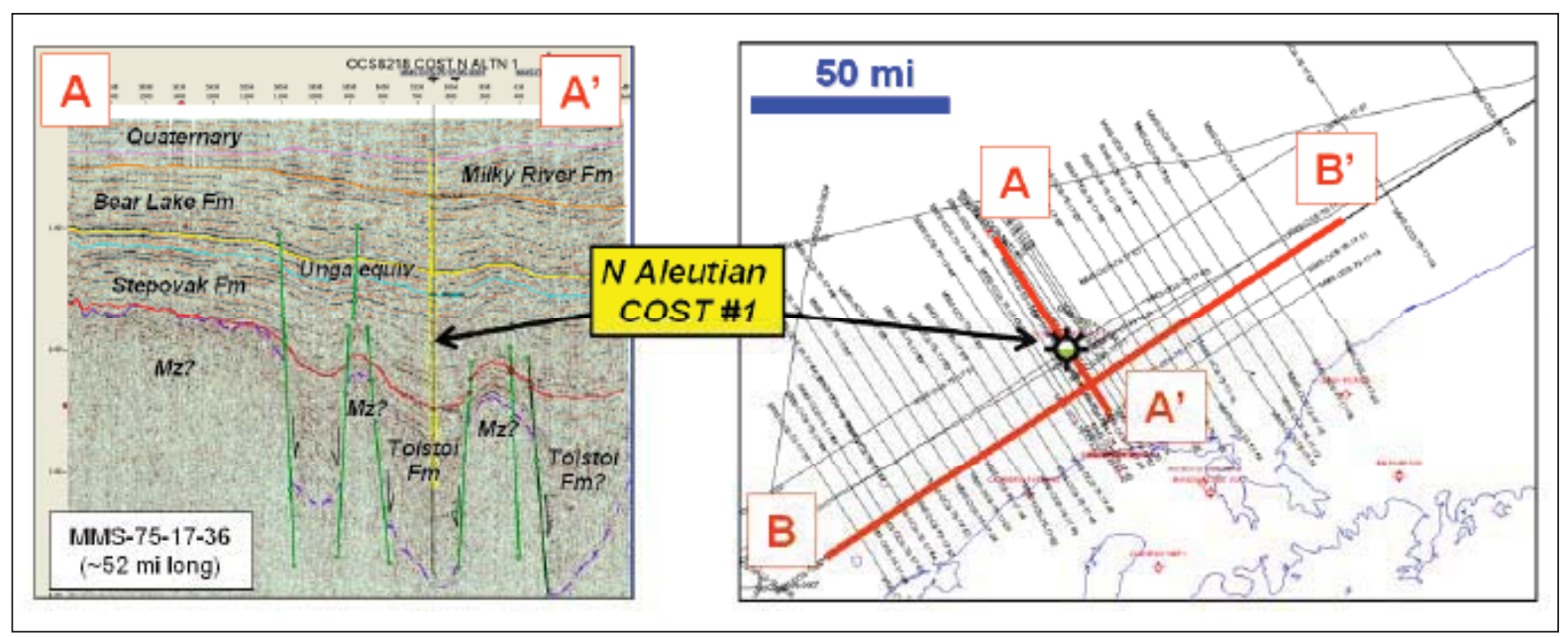

Figure 1b. Northwest-southeast seismic section and map showing the stratigraphic and structural setting of the North Aleutian COST \#1 well; from Finzel and others (2005).

Larson (1988) reported the following conventional $\mathrm{K}-\mathrm{Ar}$ ages on whole rock samples from the NAC well (Teledyne Isotopes, analysts):

$\bullet 4,882 \mathrm{~m}(16,016 \mathrm{ft})$ (core 18), altered volcanic pebble-conglomerate, $31.6 \pm 2 \mathrm{Ma}$;

$\bullet 5,081 \mathrm{~m}$ (16,670 ft; cuttings) devitrified amygdaloidal volcanics, $41 \pm 10 \mathrm{Ma}$;

-5,087-5,090 m(16,690-16,700 ft, cuttings) salt and pepper textured diabase intrusive, $47 \pm 18 \mathrm{Ma}$ (uncertainties not specified, but assumed to be $2 \sigma$ ).

The K-Ar ages show both consistencies and inconsistencies with the biostratigraphic ages reported for the well, and primary analytical data were not provided to evaluate the quality of these data, and because they reflect whole rock and not mineral separate analyses, they should be treated as suspect as evidenced by the sizable relative uncertainties of 20-40 percent.

The NAC well, $\sim 100 \mathrm{~km}$ northwest of Port Moller, was spudded September 8, 1982, to determine the stratigraphic nature of the Bristol Bay Basin in a shallow water ( $87 \mathrm{~m}$ depth) continental shelf domain. It was approximately vertically drilled $\left(<1^{\circ}\right.$ deviation from 0 to $1,749 \mathrm{~m}$ depth, increasing deviation to $3^{\circ}$ at $3,204 \mathrm{~m}$, with a maximum deviation of $4.5^{\circ}$ in the lower third of the well) to a total depth of 5,229 m (completed January 15, 1983); NAC represents one of the deepest wells drilled in Alaska (Turner, 1988). The well encountered Cenozoic strata ranging from Pleistocene/Holocene to Eocene age and was drilled in a small graben floored by Mesozoic rocks near the center of the basin. A total of 19 conventional cores (more than $100 \mathrm{~m}$ of penetrated section) were taken within the interval 1,025-5,100 m. The MMS report by Turner (1988) contains a wealth of data on the lithology, well logs, biostratigraphy, geothermal, and structural and stratigraphic setting of the well. Corrected estimates of equilibrium bottom-hole logging temperature data from three depths were reported by Flett (1988a) and yielded a $2^{\circ} \mathrm{C}$ seafloor temperature and a linear mean thermal gradient of $31^{\circ} \mathrm{C} / \mathrm{km}$. A variety of organic thermal maturity data were reported by Flett (1988b). However, vitrinite reflectance $\left(R_{o}\right)$ and spore coloration indices were difficult to evaluate due to excessive amounts of recycled organic matter. A mainly continuous vitrinite reflectance trend was observed increasing from 0.25 to 1.2 percent with increasing depth except for a possible unconformity recognized near the bottom of the well between 4,684 $\mathrm{m}$ and 4,846 $\mathrm{m}$ where $\mathrm{R}_{\mathrm{o}}$ abruptly increases from 0.6 to 0.8 percent. The corrected bottom-hole temperatures are approximately consistent with the indicated vitrinite thermal maturities, despite the abundance of recycled vitrinite observed in the well samples. Biostratigraphic data did not indicate significant erosional unconformities in the well, although the regional stratigraphy suggests possible unconformities in the middle Miocene, upper Oligocene and middle-upper Eocene sections.

Sedimentary provenance for the NAC section include Cenozoic volcanoplutonic rocks of the Aleutian magmatic arc, Mesozoic magmatic arc rocks of the Beringian Margin-Alaska Range, and Proterozoic younger rocks of interior Alaska (for example, Finzel and others, 2005; Decker and others, 1994).

\section{SAMPLE DETAILS}

Nine core samples $(1,279-5,094 \mathrm{~m}$ core depths) from the NAC well were obtained in May 1994 from the ARCO Bayview core warehouse facility by the first author. Sampled intervals and associated details are listed 
in table 1. Mineral separation followed at Geochron Laboratories (Cambridge, MA) and workable apatite and zircon splits were recovered from six of the nine samples attempted. Fission-track analysis of apatite was performed by John Murphy at the University of Wyoming and of zircon by Shari Kelley at Southern Methodist University to constrain the thermal history and provenance of the section encountered in the NAC well. Detailed analytical methods are described in Appendix 1 and an overview of the fission-track method and discussion of important compositional controls is provided in Appendix 2.

\section{AMBIENT THERMAL STRUCTURE, MATURITY DATA, AND GEOHISTORY ANALYSIS}

Burial history analyses (fig. 2) were performed using the ZetaWare GENESIS software (http://www.zetaware. com) to evaluate the thermal history of the well (Zhiyong He, oral commun., 2004). Three bottom-hole temperatures are available from 1,378 to $4,975 \mathrm{~m}$ depths (Flett, 1988a). On the basis of the well stratigraphy (yielding a mean thermal conductivity of $1.8 \mathrm{~W} / \mathrm{mK}$ ) and observed corrected bottom-hole temperature-derived geothermal gradient of $31^{\circ} \mathrm{C} / \mathrm{km}$, the present-day heat flow in well is estimated at $56 \mathrm{~mW} / \mathrm{m}^{2}$, which is significantly below that estimated for the Bristol Bay area $\left(70-90 \mathrm{~mW} / \mathrm{m}^{2}\right)$ using the recent compilation by Blackwell and Richards (2004). The in-well heat flow is within the range observed for the Alaska Peninsula by Molenaar (1996), who summarized wells in the Bristol Bay Lowland with thermal gradients in the range $29-38^{\circ} \mathrm{C} / \mathrm{km}$. These lower gradients contrast with higher gradients associated with wells to the south along the Alaska Peninsula, near the active magmatic arc, that possess gradients in excess of $34-60^{\circ} \mathrm{C} / \mathrm{km}$.

\section{RESULTS}

Fission-track data are summarized in table 2, comprising six samples in which a total of 181 apatite grains and 154 zircon grains were dated. Fission-track age and length data are summarized on depth plots in figure 3. Apatite fission-track age and length distributions are illustrated in histograms and radial plots in figure 4. Individual grain fission-track age and uranium contents are plotted for the entire core population and individual samples in figure 5. Individual apatite and zircon fission-track grain age data tables, and associated fission-track age and length plots are presented in Appendix 3. Electron microprobe analyses are not available for the NAC apatites, however, many dated apatites from other southern Alaska wells have been analyzed with the electron microprobe and summarized herein to illustrate possible compositional attributes (figs. 6, 7). The detailed discussion of these other samples is beyond the scope of this paper and the summary plots are only presented here to demonstrate some preliminary observations on nearby well samples and to highlight potential for future research.

\section{DISCUSSION \\ PROVENANCE}

All apatite and zircon populations are complex and reflect mixtures of several age components based on chi $^{2}$ statistics, which indicate multiple age populations for four of the six apatite samples and all of the zircon samples. Spectral peak analysis of the zircon fissiontrack ages show the following five peak age groups for the entire sample suite: $12 \pm 3,25 \pm 3,35 \pm 3,48 \pm 3$, and $84 \pm 3 \mathrm{Ma}$. For the deepest two Eocene cores $(3,382$ and 4,681 $\mathrm{m}$ core depths), the zircon fission-track data are consistent with a relatively simple consanguineous volcanoplutonic arc source ( 40 Ma mean zircon fission-

Table 1. Sample details for cores from the North Aleutian COST \#1 well, Alaska

\begin{tabular}{|c|c|c|c|c|c|c|c|c|c|}
\hline & \multirow[b]{2}{*}{ Depth (ft) } & \multicolumn{2}{|c|}{ Ave. Depth } & \multicolumn{2}{|c|}{ Temperature } & \multicolumn{4}{|c|}{ Approx. depositional } \\
\hline & & (ft) & (m) & ${ }^{\circ} \mathbf{C}$ & core\# & Epoch & Ma & Formation & Lithology \\
\hline 94NAC1 & $4,191-4,199$ & 4,195 & 1,279 & 38 & $\mathrm{C} 2$ & $\overline{\text { Middle Miocene }}$ & 15 & Bear Lake/Unga & fg volc ss/tuff \\
\hline 94NAC2 & $5,970-5,999$ & 5,985 & 1,824 & 55 & $\mathrm{C} 4$ & Late Oligocene & 24 & Stepovak & fg volc ss \\
\hline 94NAC3 & $8,056-8,069$ & 8,063 & 2,458 & 75 & $\mathrm{C} 7$ & Early Oligocene & 29 & Stepovak & vfg ss/siltstone \\
\hline 94NAC4 & $8,640-8,648$ & 8,644 & 2,635 & 80 & $\mathrm{C} 8$ & Early Oligocene & 33 & Stepovak & vfg ss \\
\hline 94NAC5 & $9,951-9,959$ & 9,955 & 3,304 & 93 & $\mathrm{C} 10$ & Late Eocene & 38 & Stepovak & vfg volc ss/tuff \\
\hline 94NAC6 & $11,089-11,100$ & 11,095 & 3,382 & 104 & $\mathrm{C} 13$ & Eocene & 40 & Tolstoi & f-mg xl lith tuff \\
\hline 94NAC7 & $12,249-12,257$ & 12,253 & 3,735 & 115 & $\mathrm{C} 14$ & Eocene & 42 & Tolstoi & vfg volc ss/tuff \\
\hline 94NAC8 & $15,355-15,362$ & 15,359 & 4,681 & 144 & $\mathrm{C} 17$ & Eocene & 47 & Tolstoi & f-mg volc ss \\
\hline 94NAC9 & $16,709-16,714$ & 16,712 & 5,094 & 157 & $\mathrm{C} 19$ & Eocene & 50 & Tolstoi & lapilli tuff \\
\hline
\end{tabular}

\footnotetext{
Notes
}

Temperatures interpolated from corrected bottom hole temperatures; subsea temperature $=2{ }^{\circ} \mathrm{C}$; linear geothermal gradient $=31.1^{\circ} \mathrm{C} / \mathrm{km}$. Depositional epoch from Turner (1988); absolute ages approximated using the ICS timescale (http://www.stratigraphy.org).

Formation nomenclature from Finzel and others (2005); lithologies based on thin section inspection.

$\mathrm{v}=$ very, $\mathrm{f}=$ =fine, $\mathrm{m}=$ medium, $\mathrm{g}=$ grained, volc=volcaniclastic, $\mathrm{ss}=$ sandstone. 
Table 2. Summary of apatite and zircon fission-track age data for the North Aleutian COST \#1 well, Alaska

\begin{tabular}{|c|c|c|c|c|c|c|c|c|c|c|}
\hline & $\begin{array}{l}\text { Ave. } \\
\text { (ft) }\end{array}$ & $\begin{array}{r}\text { Depth } \\
\text { (m) }\end{array}$ & $\begin{array}{c}\text { Temp. } \\
{ }^{\circ} \mathrm{C}\end{array}$ & $\begin{array}{c}\text { Depos. } \\
\text { age Ma }\end{array}$ & $\begin{array}{l}\text { Depos. } \\
\text { Epoch }\end{array}$ & $\begin{array}{c}\text { Apatite } \\
\text { age (Ma) } \\
\text { (no. grains) }\end{array}$ & $\begin{array}{c}\text { Apatite } \\
\text { mtl ( } \mu \mathrm{m}) \\
(\mathrm{sd}, \mathrm{ntr})\end{array}$ & $\begin{array}{c}\text { Apatite } \\
\text { U } \\
\text { (ppm) }\end{array}$ & $\begin{array}{c}\text { Zircon } \\
\text { age (Ma) } \\
\text { (no. grains) }\end{array}$ & $\begin{array}{c}\text { Zircon } \\
\mathbf{U} \\
(\mathrm{ppm})\end{array}$ \\
\hline 94NAC1 & 4,195 & 1,279 & 38 & 15 & M Mioc & $30 \pm 4.0(31)$ & $12.2 \pm 0.25(2.2,75)$ & 29 & $69 \pm 10(20)$ & 580 \\
\hline 94NAC2 & 5,985 & 1,824 & 55 & 28 & L Olig & $32 \pm 3.1(31)$ & $12.6 \pm 0.16(1.6,100)$ & 20 & $58 \pm 5.2(30)$ & 617 \\
\hline 94NAC3 & 8,063 & 2,458 & 75 & 33 & E Olig & $74 \pm 7.4(31)$ & $12.5 \pm 0.17(1.7,106)$ & 15 & $50 \pm 5.5(29)$ & 453 \\
\hline 94NAC5 & 9,955 & 3,304 & 93 & 38 & L Eoc & $35 \pm 3.7(31)$ & $13.4 \pm 0.26(2.6,101)$ & 7 & $47 \pm 4(41)$ & 573 \\
\hline 94NAC6 & 11,095 & 3,382 & 104 & 43 & Eoc & $50 \pm 5.6(26)$ & $13.3 \pm 0.24(1.9,63)$ & 3 & $37 \pm 3(20)$ & 515 \\
\hline 94NAC8 & 15,359 & 4,681 & 144 & 50 & Eoc & $8.9 \pm 1.7(31)$ & $9.0 \pm 1.3(3.1,6)$ & 4 & $39 \pm 4(14)$ & 428 \\
\hline
\end{tabular}

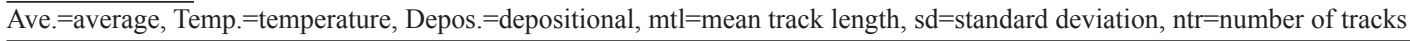

track ages, yet failing the $\mathrm{chi}^{2}$ test for a single population) and a more complex assemblage of Mesozoic plutonic basement rocks and Cenozoic volcanic source terranes for younger Eocene to Miocene deposits based on four cores shallower than 3,034 $\mathrm{m}$. The mean zircon ages of the shallower four cores range from 53 to $82 \mathrm{Ma}$, systematically increasing in age going upsection, with individual grain ages in the range 20-200 Ma. All samples show a broadly negative correlation between zircon fission-track grain age and uranium content. The zircon fission-track ages from Eocene to Miocene cores indicate systematic Mesozoic to Cenozoic source terranes with ages averaging 10-50 m.y. older than depositional ages. Apatite grains are therefore inferred to possess a detrital age component that may be 10-50 m.y. older than depositional ages. The shallowest four samples contain zircons with the widest range in both fission-track age and uranium content, indicating a more complex provenance than that of the deeper two samples, which show very limited age and uranium content ranges.

Apatites display similar, yet slightly contrasting trends, with the shallowest three samples similarly possessing the widest range in both fission-track age and uranium content, whereas the three deeper samples possess apatites with limited uranium contents, but only samples NAC5 and NAC8 show limited fission-track age range (fig. 5). Both zircon fission-track ages and uranium contents both systematically decrease with increasing depth (table 2, figs. 3 and 5). Similarly, apatite uranium content also decreases with increasing depth, whereas apatite fission-track age shows a more complex depth trend due to partial resetting of the deepest sample, NAC8. The zircon and apatite uranium contents are consistent with these phases having been derived by progressive unroofing of an evolving Mesozoic to Cenozoic magmatic arc terrane with the deepest samples representing a more primitive (lower-uranium) source magmatic rocks and the youngest samples representing more evolved (higher-uranium) magmatic rocks. Therefore, initially primitive late Mesozoic- to early
Cenozoic-age mafic to intermediate magmatic rocks represented the dominant provenance during the Eocene deposition, whereas the younger Oligocene to Miocene deposits reflect more diverse provenance including late Mesozoic- to early Cenozoic-age mafic, intermediate, and felsic magmatic rocks.

\section{THERMAL HISTORY}

Five of the six samples possess apatite central fission-track ages within analytical uncertainty of, or older than, depositional ages; mean track lengths vary between 12 and $13 \mu \mathrm{m}$ (fig. 5). These samples currently reside at temperatures of $38-100 \pm 10^{\circ} \mathrm{C}$, below or within the zone of fluorine-rich apatite fission track partial stability $\left(\sim 60-120^{\circ} \mathrm{C}\right)$, hence the ages and track length distributions may reflect minimal post-depositional annealing and age reduction. The deepest sample, NAC8, however, currently resides at a temperature of $144^{\circ} \mathrm{C}$, significantly above the apatite fission-track annealing temperature $\left(120-130^{\circ} \mathrm{C}\right)$, yet displays an apatite fission-track age of $9 \mathrm{Ma}$, reflecting a 75-90 percent age reduction, and a mean track length of $9 \mu \mathrm{m}$, reflecting a 40 percent length reduction. Based on the abundance of chlorine- and hydroxyl-rich apatites observed in southern Alaska wells and apatites in general (figs. 6, 7), the NAC apatites are likely to possess similar diverse anion compositions, and therefore require higher fission-track closure temperatures of $130-150^{\circ} \mathrm{C}$. If NAC8 apatites are fluorine-rich, then the apatite age and length data are more consistent with a sample that has experienced temperatures of $100-120^{\circ} \mathrm{C}$ for the last $1-10 \mathrm{~m} . \mathrm{y}$., significantly below the observed $144^{\circ} \mathrm{C}$ temperature based on the corrected bottom-hole temperatures. It is more likely that the NAC8 apatites contain a significant population of chlorine- and hydroxyl-rich (1-2 wt \%) grains, consistent with the indicated thermal history assuming the present-day heat flow of $56 \mathrm{~mW} / \mathrm{m}^{2}$ has existed in the past. As shown in the apatite fission-track age-chlorine plots in figure $6 \mathrm{a}$, the Lower Cook Inlet COST well and many others in the region contain a majority of apatites with $0.5-2$ wt \% 

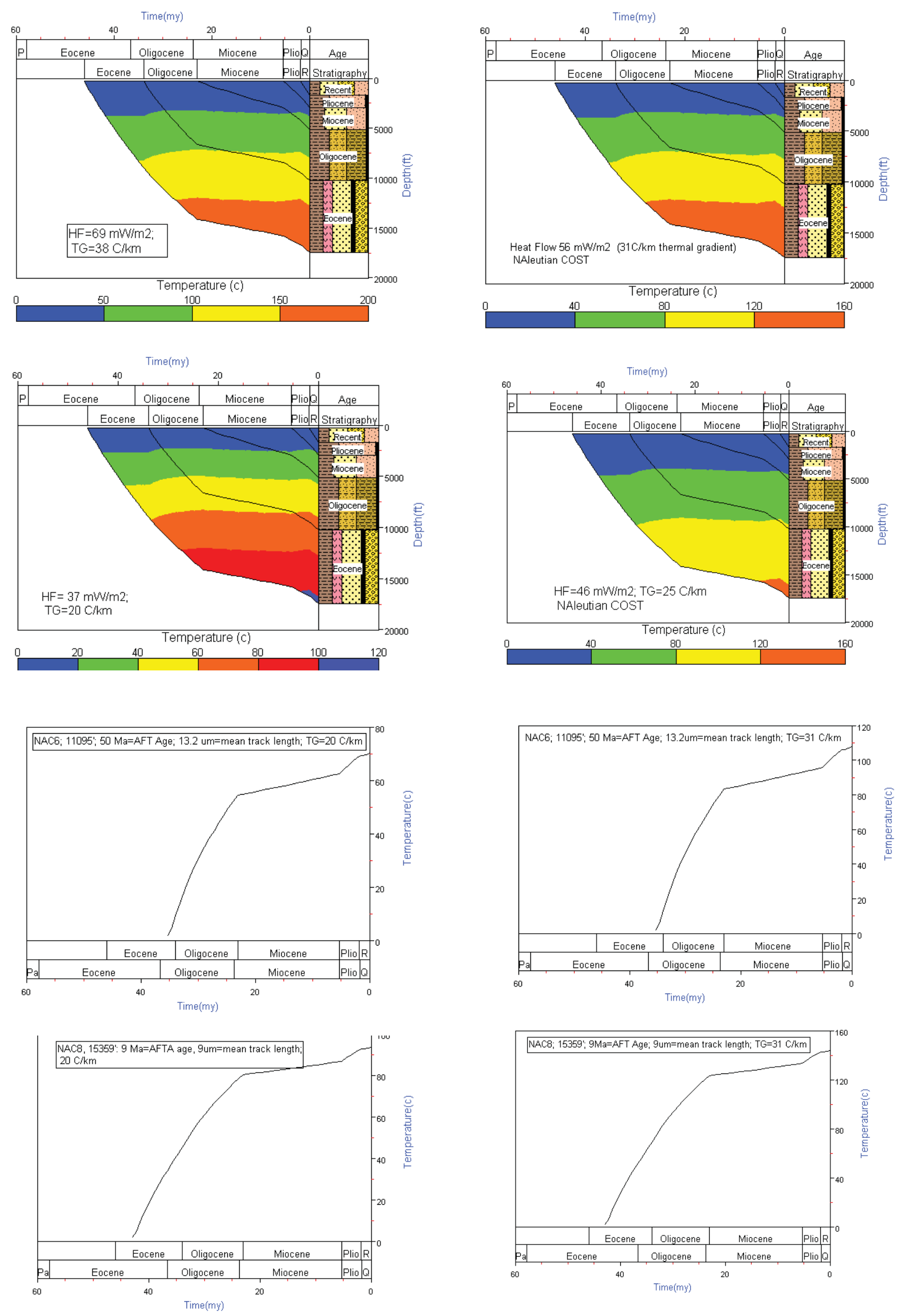

Figure 2. GENESIS burial history plots for the North Aleutian COST \#1 well showing thermal evolution for various heat flow conditions (top four plots); GENESIS-derived thermal evolution plots for the two deepest samples (NAC6 and NAC8) for two possible thermal gradients. 

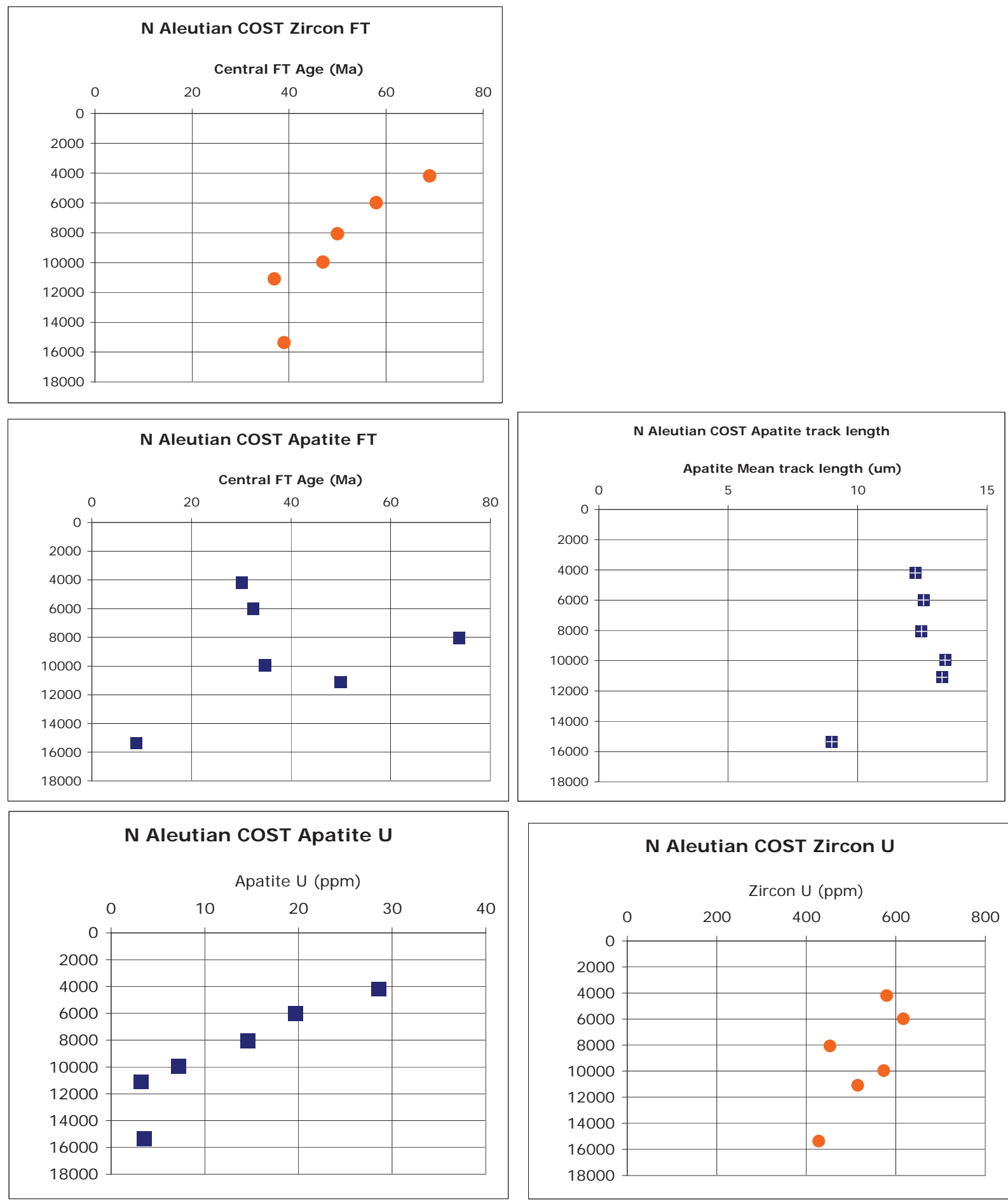

\section{N Aleutian COST Zircon U}

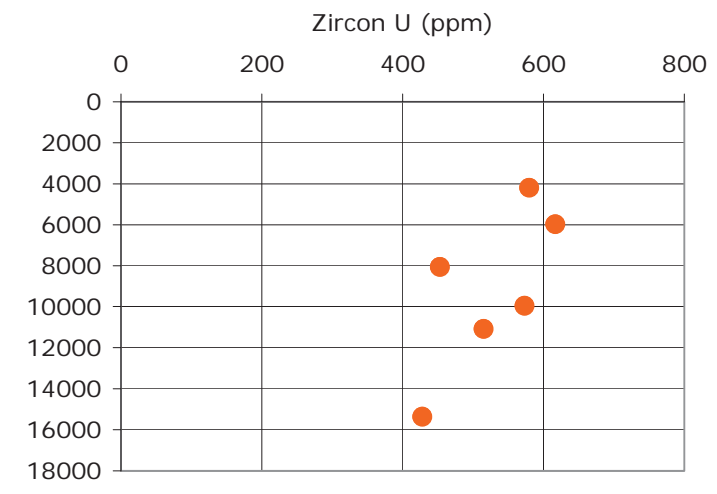

Figure 3. North Aleutian COST \#1 well plots showing the variation in zircon and apatite fission-track age and uranium contents, and apatite mean fission-track length as a function of core depth. Apatite and zircon fission-track age standard deviations are 10 percent relative for a given sample, whereas uranium contents possess more variability, with standard deviations ranging from 10 to 90 percent relative; apatite fission-track length standard errors average $\sim 0.2 \mu \mathrm{m}$, with standard deviations of $\sim 2 \mu \mathrm{m}$. 


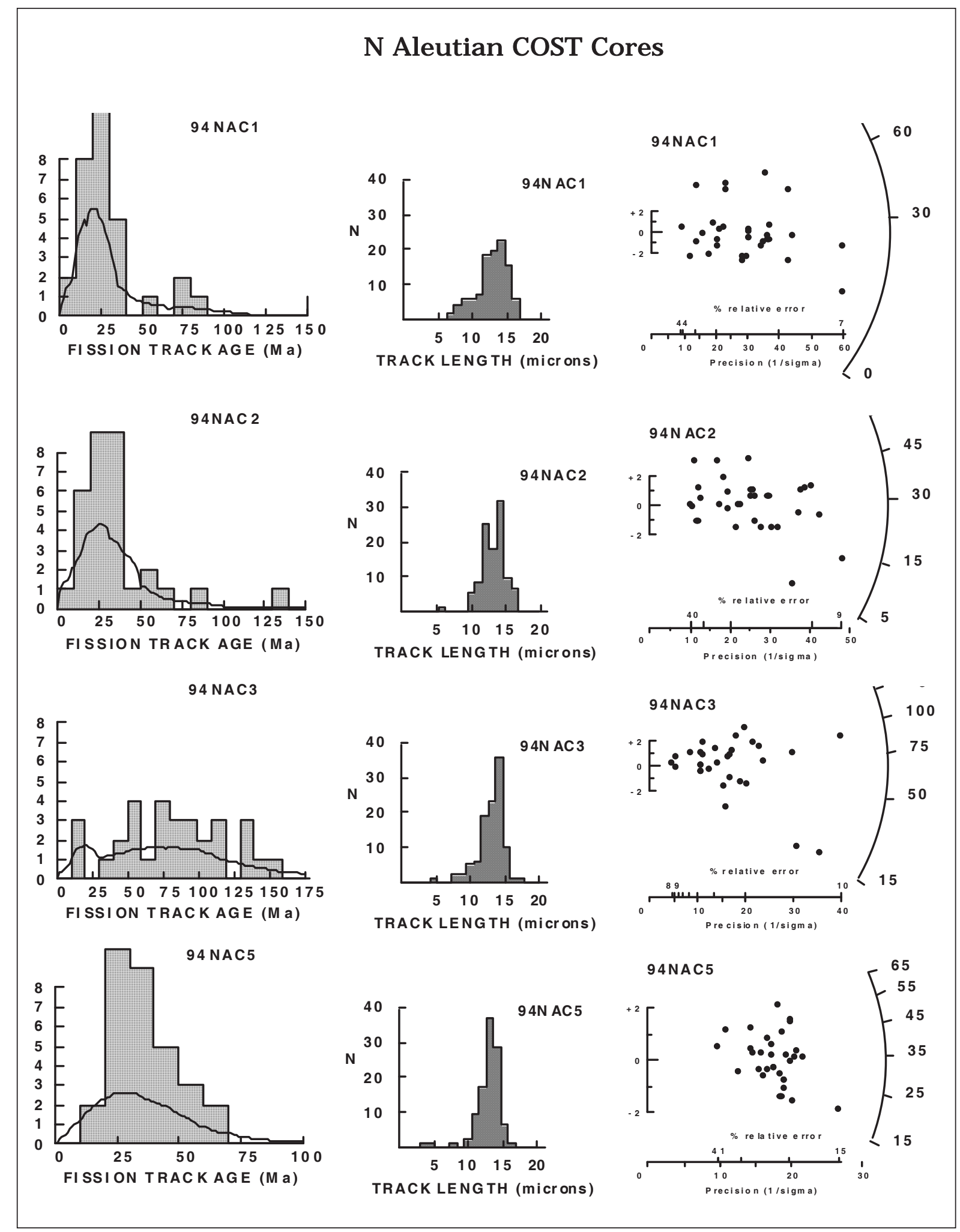

Figure 4. Apatite fission-track age and length histograms and radial plots for the North Aleutian COST \#1 well. 


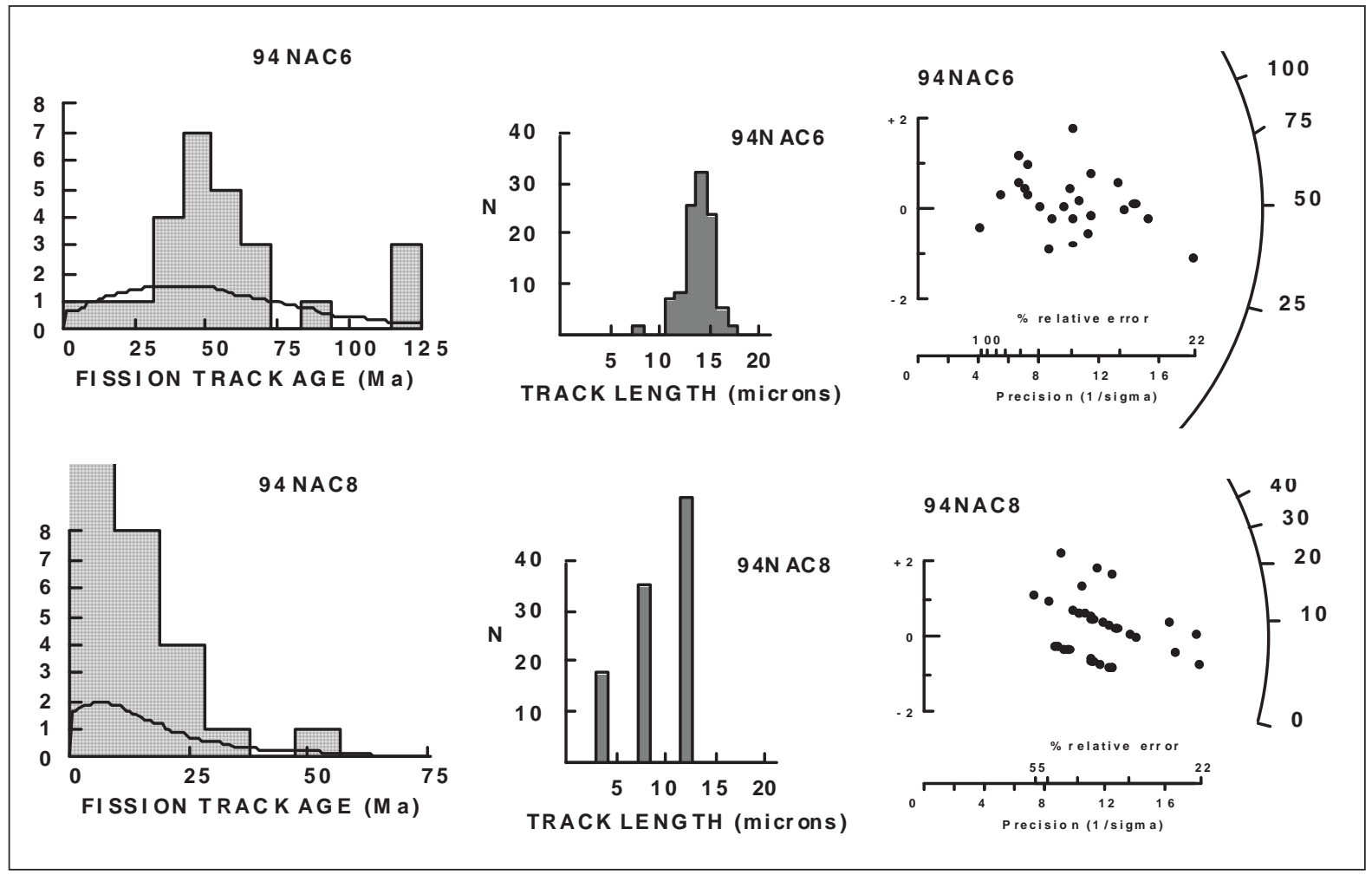

Figure 4 (continued). Apatite fission-track age and length histograms and radial plots for the North Aleutian COST \#1 well.
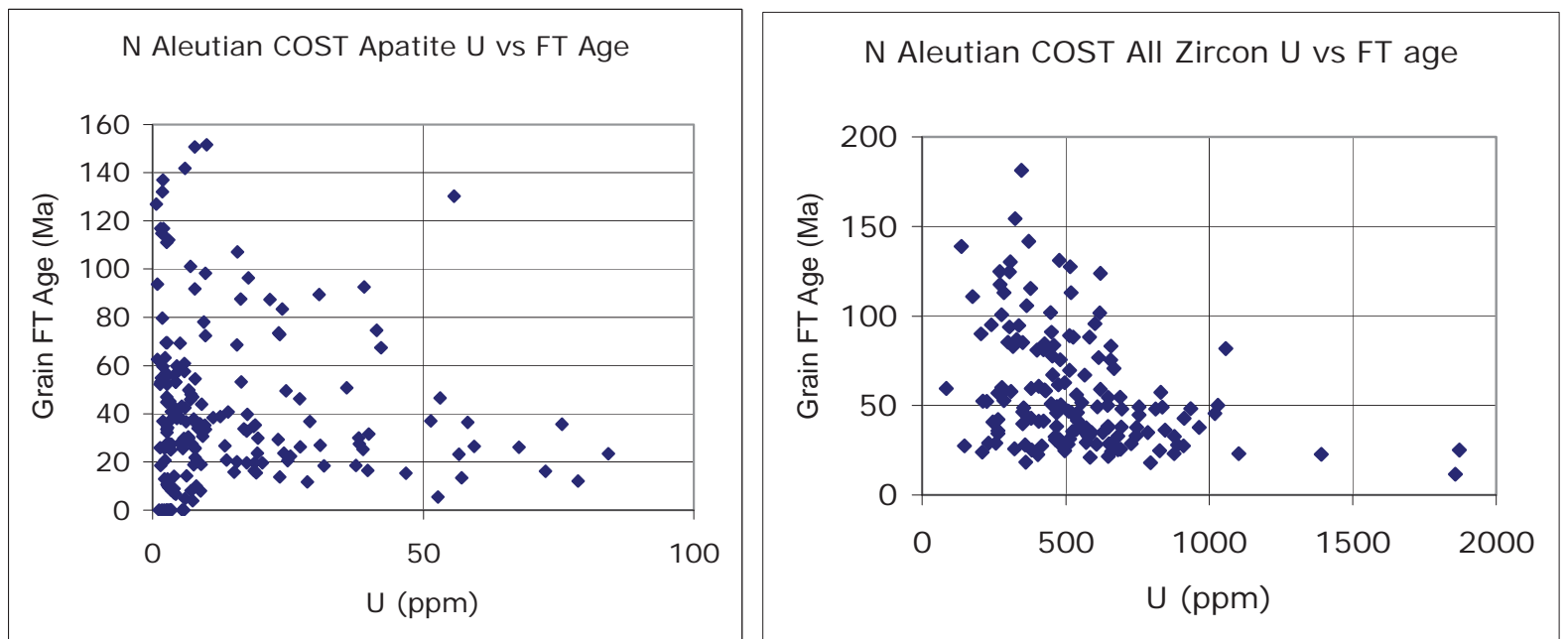

Figure 5a. Individual fission-track grain age versus uranium content for all North Aleutian COST \#1 well apatites (left) and zircons (right). 

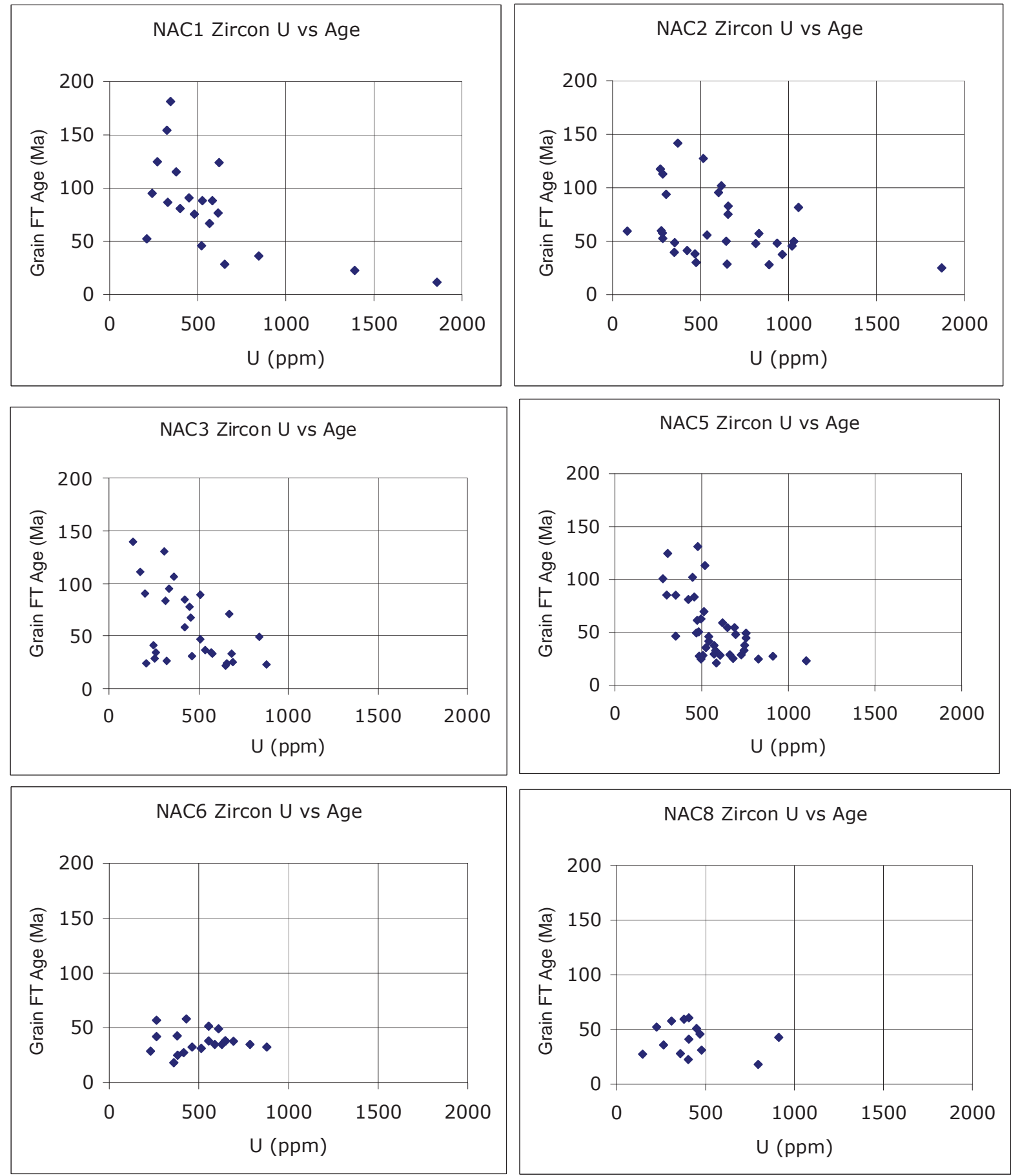

Figure 5b. Individual zircon fission-track grain age versus uranium content for individual North Aleutian COST \#1 well samples. 

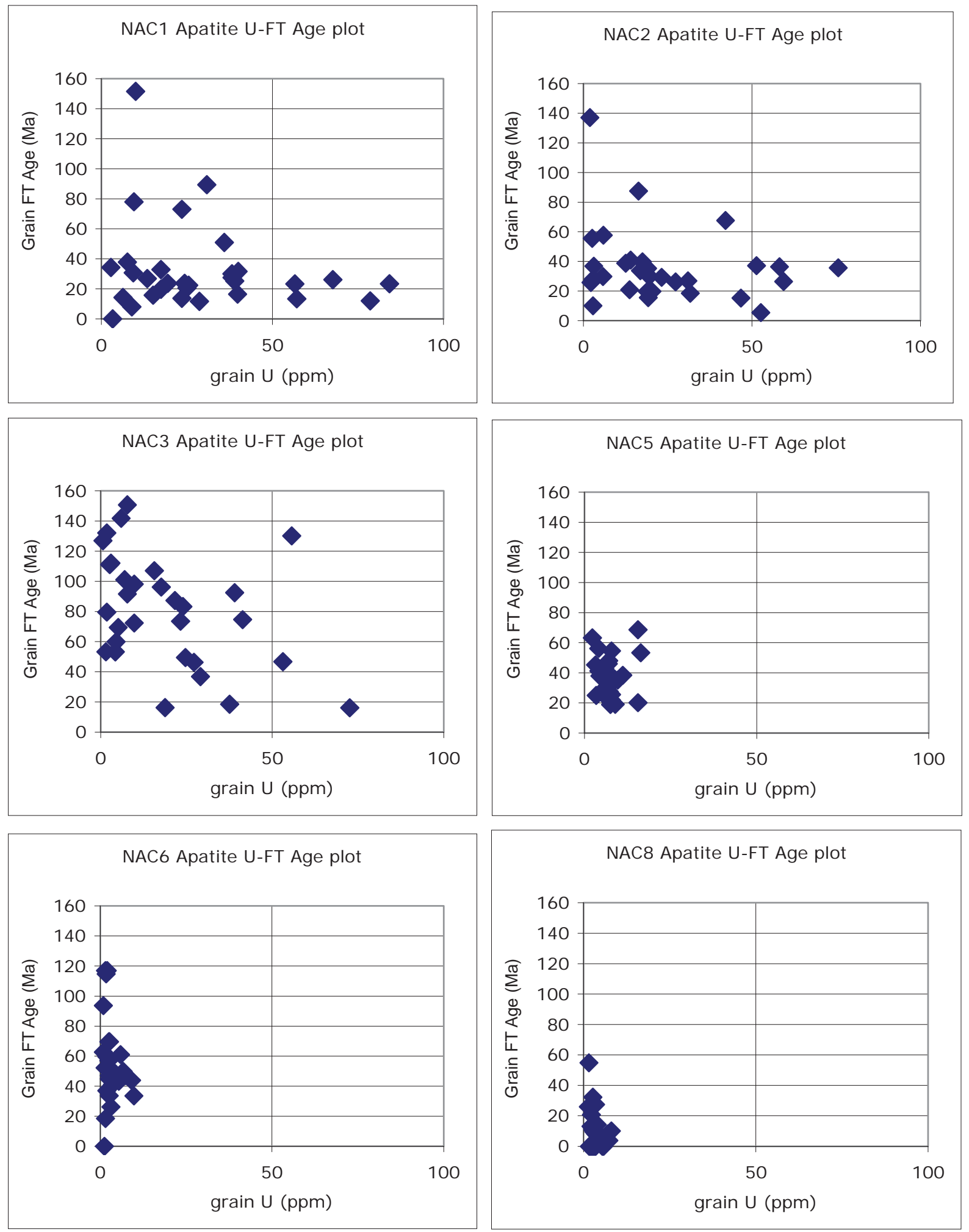

Figure $5 b$ (continued). Individual zircon fission-track grain age versus uranium content for individual North Aleutian COST \#1 well samples. 

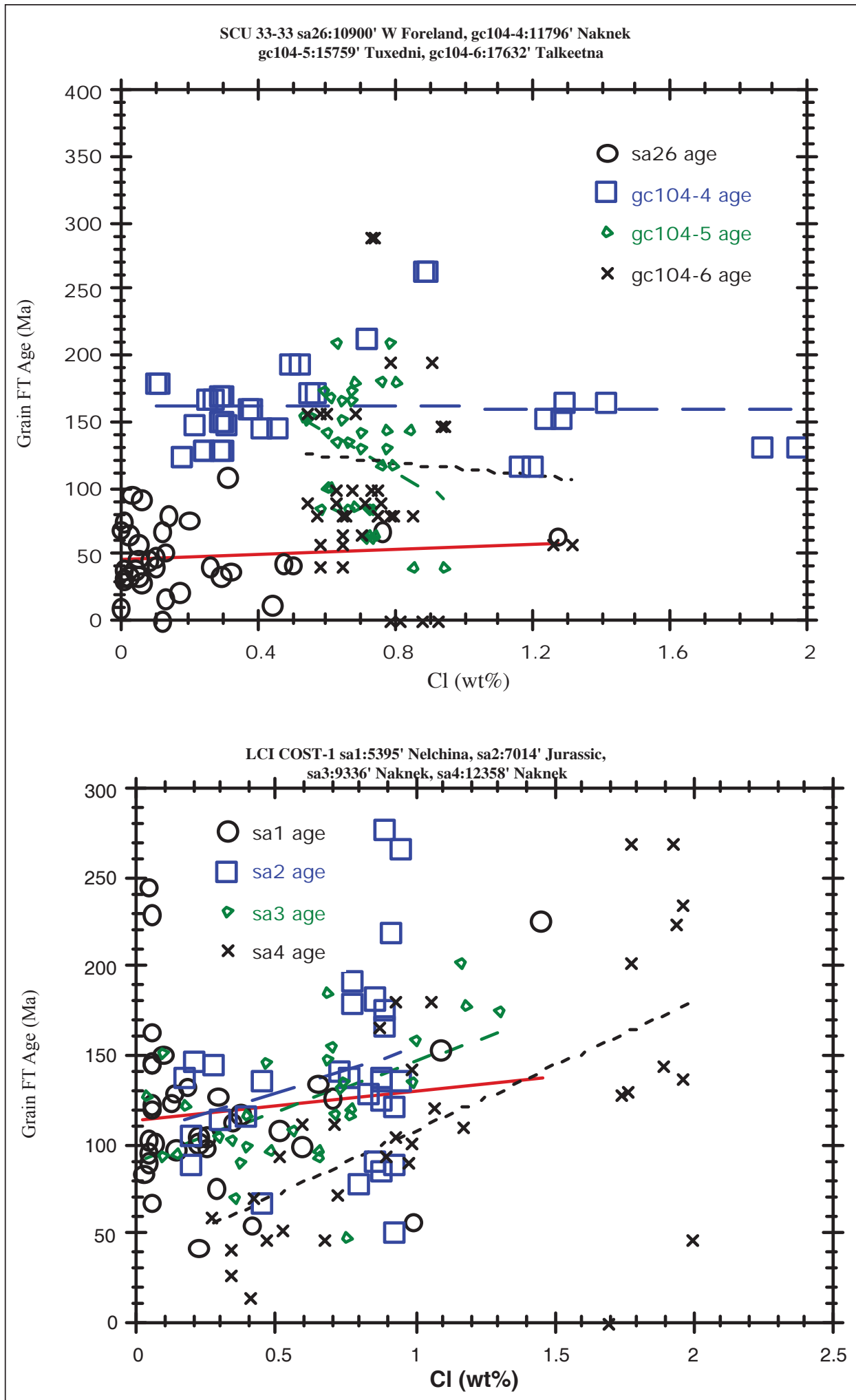

Figure 6a. Apatite fission-track grain age versus grain chlorine content for samples from the Lower Cook Inlet COST \#1 and SCU 33-33 wells, Lower Cook Inlet, Alaska (Cl by wavelength-dispersive electron microprobe analysis of dated grains; Bergman, unpublished data). 


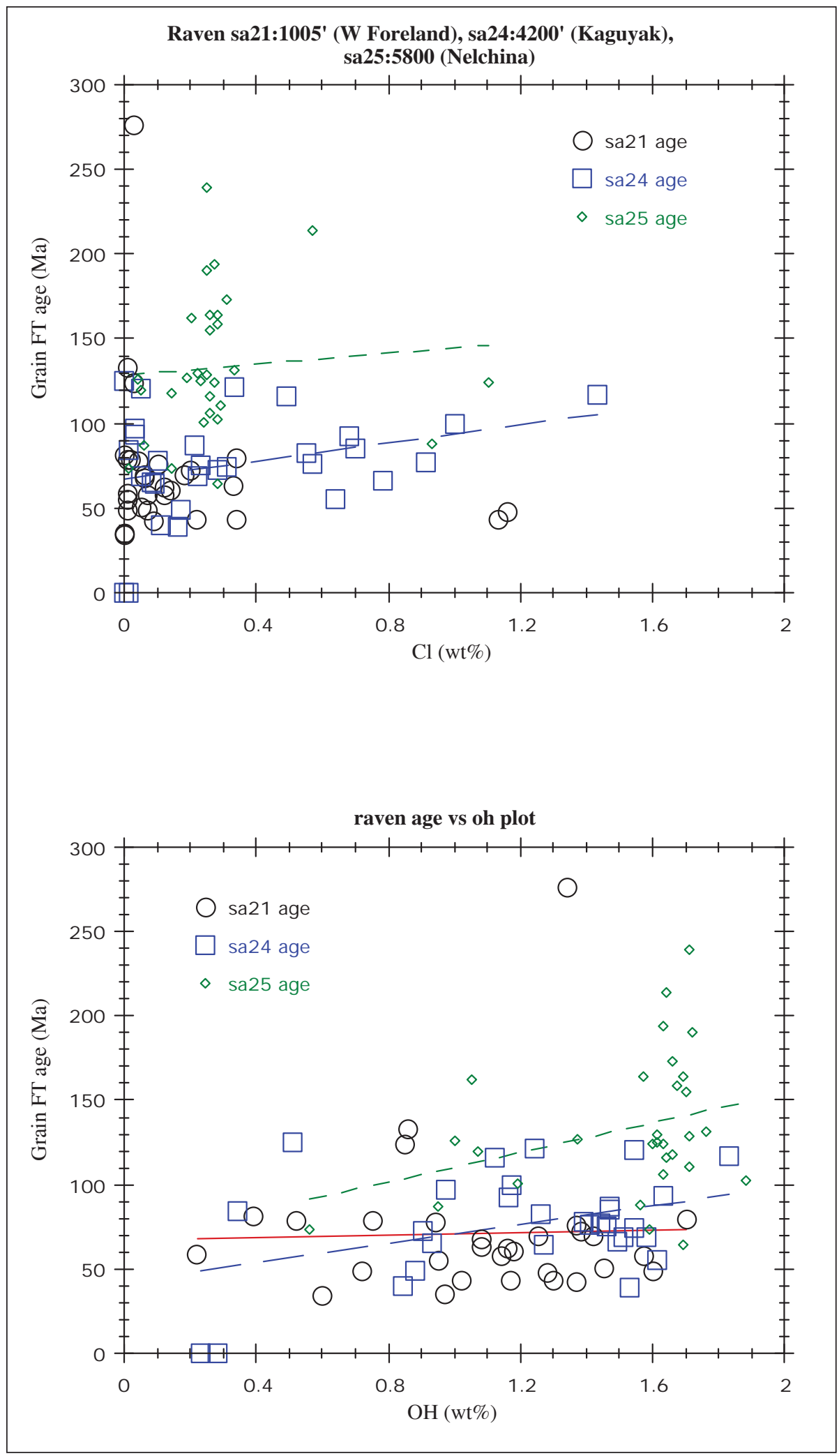

Figure 6b. Apatite fission-track grain age versus grain chlorine and hydroxyl contents for samples from the Raven \#1 well, Lower Cook Inlet, Alaska (Cl and F by wavelength-dispersive electron microprobe analysis of dated grains; OH calculated by difference assuming anion stoichiometry; Bergman, unpublished data). 

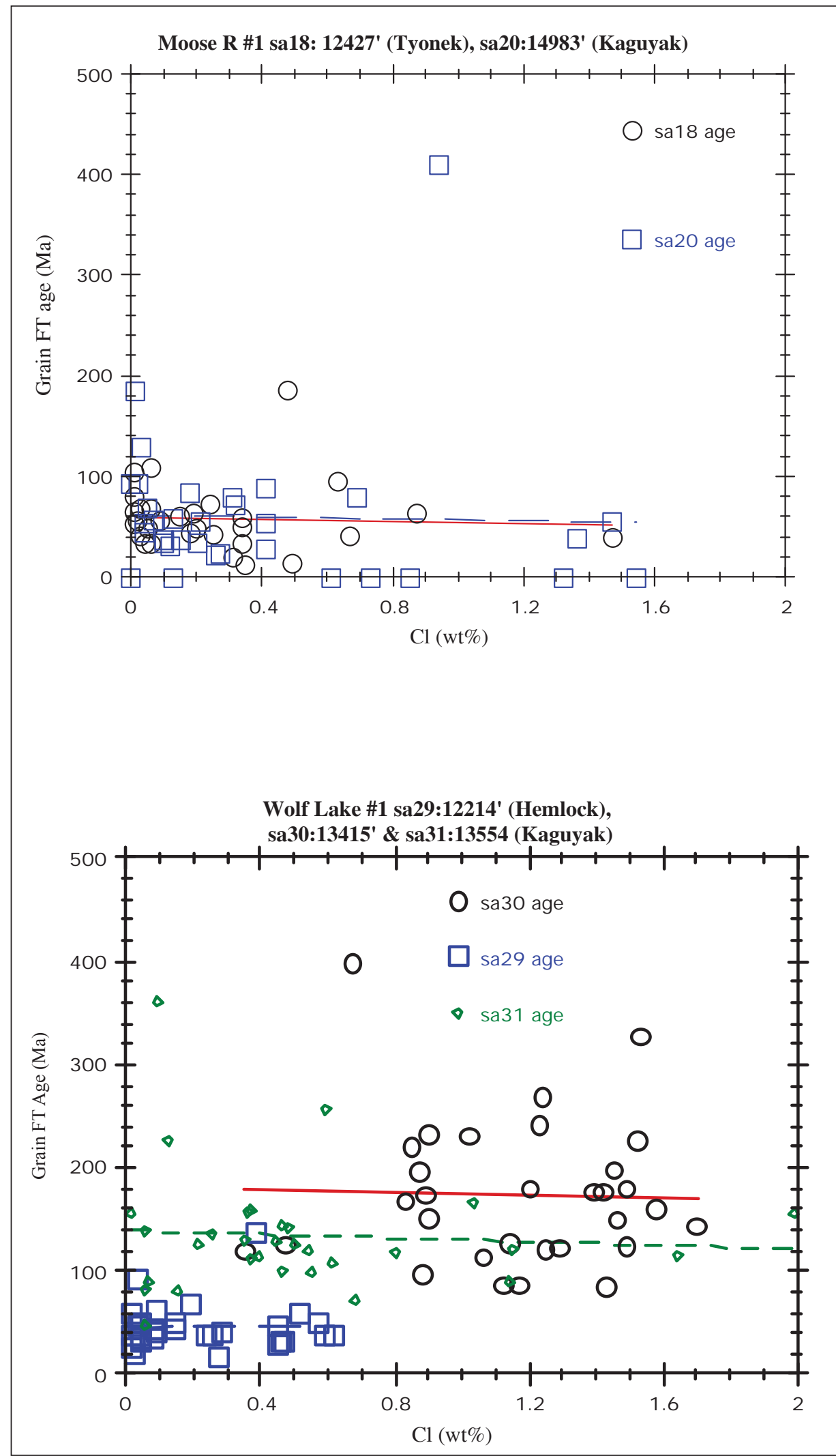

Figure 6c. Apatite fission-track grain age versus grain chlorine content for samples from the Wolf Lake \#1 and Moose River \#1 wells, Lower Cook Inlet, Alaska (Cl by wavelength-dispersive electron microprobe analysis of dated grains; Bergman, unpublished data). 


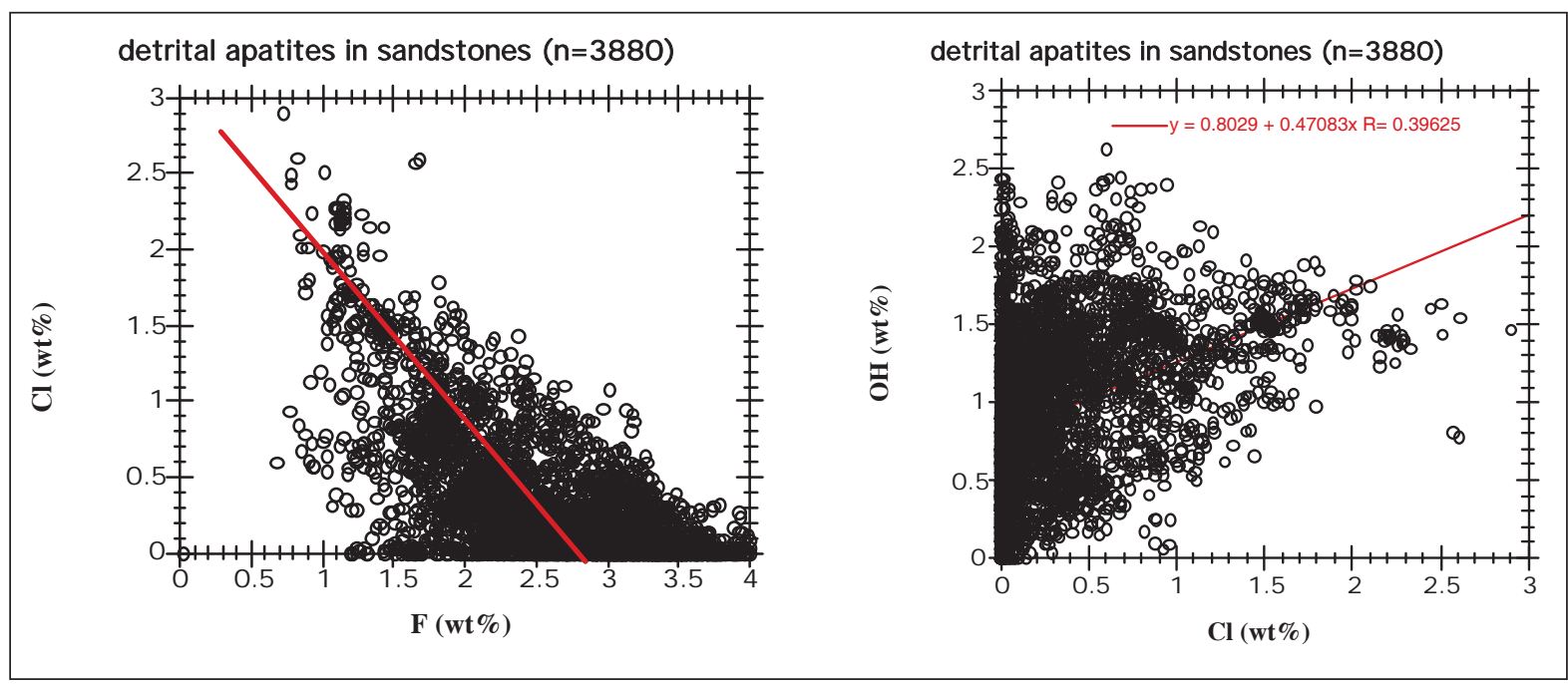

Figure 7a. Plots showing the relationships between various anions in dated apatite from several hundred worldwide sandstone samples showing a wide range in anion composition, and a positive correlation between chlorine and hydroxyl and negative correlation between fluorine and chlorine ( $\mathrm{Cl}$ and $\mathrm{F}$ by wavelength-dispersive electron microprobe analysis of dated grains; OH calculated by difference assuming anion stoichiometry; Bergman, unpublished data).

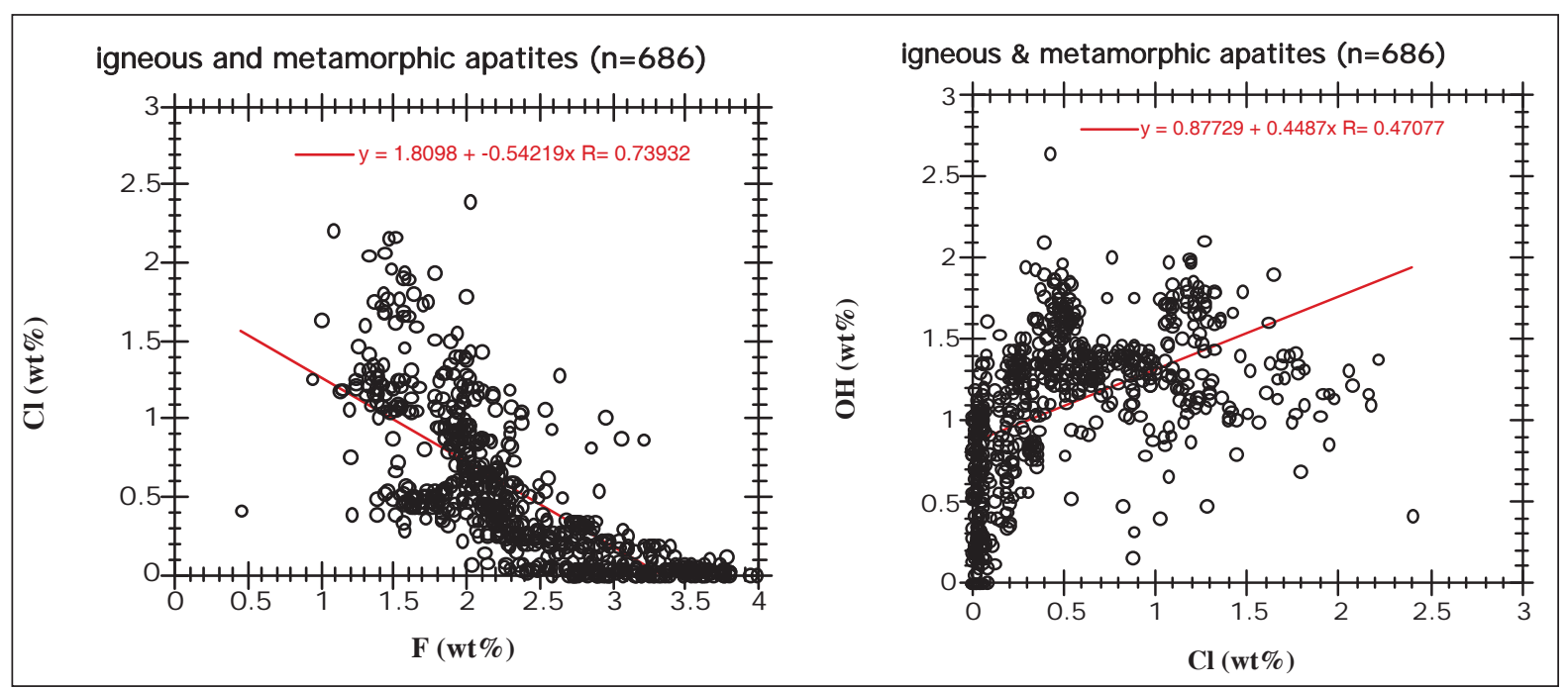

Figure 7b. Plots showing the relationships between the various anions in dated apatite grains from worldwide igneous and metamorphic rock samples showing a wide range in anion composition, and a positive correlation between chlorine and hydroxyl and negative correlation between fluorine and chlorine ( $\mathrm{Cl}$ and $\mathrm{F}$ by wavelength-dispersive electron microprobe analysis of dated grains; OH calculated by difference assuming anion stoichiometry; Bergman, unpublished data). 
chlorine, and positive fission track age-chlorine content correlations, suggesting that higher apatite fission-track closure temperatures of $130-150^{\circ} \mathrm{C}$ may be more appropriate for southern Alaska well apatite fission-track analysis interpretations.

\section{CONCLUSIONS}

Corrected bottom-hole temperatures, combined with inferred lithology-dependent thermal conductivities indicate a present-day day heat flow of $56 \mathrm{~mW} / \mathrm{m}^{2}$ for the NAC well site. The stratigraphic section encountered in the NAC well is currently at or near maximum experienced burial temperatures. Both the vitrinite and apatite fission-track data are consistent with a simple Cenozoic burial history and a Cenozoic heat flow near or below $56 \mathrm{~mW} / \mathrm{m}^{2}$. Due to an abundance of chlorineand hydroxyl-rich apatites observed in southern Alaska wells, slightly higher closure temperatures may be appropriate for the valid interpretation of apatite fission track thermochronology data. New apatite and zircon FT and Uranium data provide constraints on the nature of the provenance of volcaniclastic and sedimentary strata encountered in the Bristol Bay Basin.

\section{ACKNOWLEDGMENTS}

These data were released by ARCO in 2000; many thanks to Barry Davis. The authors thank ARCO Research Thermochronology Lab colleagues Jeff Corrigan and James Talbot, ARCO Alaska colleagues John Decker and Dave Doherty, Alaska Division of Geological \& Geophysical Surveys colleagues Rocky Reifenstuhl and Jim Clough and former colleague Mark Robinson, as well as Alaska Division of Oil \& Gas colleague Paul Decker, for their valued support. Zhiyong He kindly provided access to the Genesis burial modeling software for this study. Paul Layer and Rocky Reifenstuhl provided thoughtful reviews that improved the manuscript and for which the authors are most appreciative.

\section{REFERENCES CITED}

Blackwell, D.D., and Richards, M., editors, 2004, Geothermal Map of North America: Tulsa, OK, American Association of Petroleum Geologists, 1 sheet, scale 1:6,500,000; http://www.smu.edu/geothermal/ 2004NAMap/2004NAmap.htm.

Bond, G.C., Lewis, S.D., Taber, J., Steckler, M.S., and Kominz, M.A., 1988, Evidence for formation of a flexural back arc basin by compression and crustal thickening in the central Alaska Peninsula: Geology, v. 16 , p. $1,147-1,150$.

Carlson, W.D., 1990, Mechanisms and kinetics of apatite fission track annealing: American Mineralogist, v. 75, p. 1,120-1,139.
Carlson, W.D., Donelick, R.A., and Ketcham, R.A., 1999, Variability of apatite fission track annealing kinetics I; Experimental results: American Mineralogist, v. 84 , p. 1,213-1,223.

Crowley, K.D., 1985, Thermal significance of fission track length distributions: Nuclear Tracks, v. 10, p. 311-322.

Decker, J., Bergman, S.C., Blodgett, R.B., Box, S.E., Bundtzen, T.K., Clough, J.G., Coonrad, W.L., Gilbert, W.G., Miller, M.L., Murphy, J.M., Robinson, M.S., and Wallace, W.K., 1994, Geology of southwestern Alaska, in Plafker, G., and Berg, H.C., eds., The geology of Alaska: Boulder, CO, Geological Society of America, The Geology of North America, v. G1, p. 285-310.

DeMets, Charles, Gordon, R.G., Argus, D.F., and Stein, Seth, 1994, Effects of recent revisions to the geomagnetic reversal time scale on estimates of current plate motions: Geophysical Research Letters, v. 21, p. 2,191-2,194.

Detterman, R.L., Case, J.E., Miller, J.W., Wilson, F.H., and Yount, M.E., 1996, Stratigraphic framework of the Alaska Peninsula: U.S. Geological Survey Bulletin 1969-A, $74 \mathrm{p}$.

Dodson, M.H., and McClelland-Brown, E., 1985, Isotopic and paleomagnetic evidence for rates of cooling, uplift, and erosion, in Snelling, N.J., ed., The chronology of the geological record: Geological Society of London, Memoir 10, p. 315-325.

Donelick, R.A., Ketcham, R.A., and Carlson, W.D., 1999, Variability of apatite fission-track annealing kinetics; II, Crystallographic orientation effects: American Mineralogist, v. 84, p. 1,224-1,234.

Donelick, R.A., O'Sullivan, P.B, and Ketcham, R.A., 2005, Apatite fission-track analysis: Reviews in Mineralogy and Geochemistry, v. 58, no. 1, p. 49-94.

Finzel, E.S., Reifenstuhl, R.R., Decker, P.L., and Ridgway, K.D., 2005, Sedimentology, stratigraphy, and hydrocarbon reservoir-source rock potential, using surface and subsurface data, of Tertiary and Mesozoic strata, Bristol Bay Basin and Alaska Peninsula: Alaska Division of Geological \& Geophysical Surveys Preliminary Interpretive Report 2005-4, 67 p.

Fleischer, R.L., Price, P.B., and Walker, R.M., 1975, Nuclear tracks in solids: Los Angeles, University of California Press, 605 p.

Flett, T.O., 1988a, Geothermal gradient, in Turner, R.F., ed., Geological and operational summary, North Aleutian Shelf COST No. 1 well, Bering Sea, Alaska: U.S. Minerals Management Service, OCS Report MMS 88-0089, p. 180-183.

Flett, T.O., 1988b, Organic geochemistry, in Turner, R.F., ed., Geological and operational summary, North Aleutian Shelf COST No. 1 well, Bering Sea, Alaska: U.S. 
Minerals Management Service, OCS Report MMS 88-0089, p. 184-202.

Gallagher, K., Brown, R.W., and Johnson, C., 1998, Fission track analysis and its applications to geological problems: Annual Reviews of Earth and Planetary Sciences, v. 26, p. 519-572.

Gleadow, A.J.W., and Duddy, I.R., 1981, A natural long term annealing experiment for apatite: Nuclear Tracks, v. 5, p. 169-174.

Gleadow, A.J.W., Duddy, I.R., and Lovering, J.F., 1983. Fission track analysis; A new tool for the evaluation of thermal histories and hydrocarbon potential: Australian Petroleum Association Journal, v. 23, p. $93-102$.

Gradstein, F.M., Ogg, J.G., Smith, A.G., Agterberg, F.P., Bleeker, W., Cooper, R.A., Davydov, V., Gibbard, P., Hinnov, L.A., House, M.R., Lourens, L., Luterbacher, H.P., McArthur, J., Melchin, M.J., Robb, L.J., Shergold, J., Villeneuve, M., Wardlaw, B.R., Ali, J., Brinkhuis, H., Hilgen, F.J., Hooker, J., Howarth, R.J., Knoll, A.H., Laskar, J., Monechi, S., Plumb, K.A., Powell, J., Raffi, I., Röhl, U., Sadler, P., Sanfilippo, A., Schmitz, B., Shackleton, N.J., Shields, G.A., Strauss, H., Van Dam, J., van Kolfschoten, T., Veizer, J., and Wilson, D., 2004, A geologic time scale 2004: Cambridge University Press, 589 p.

Green, P.F., Duddy, I.R., Gleadow, A.J.W., and Lovering, J.F., 1989, Apatite fission track analysis as a paleotemperature indicator for hydrocarbon exploration, in Naeser, N.D., and McCulloch, T.H., eds., Thermal history of sedimentary basins; methods and case histories: New York, Springer-Verlag, p. 181-195.

Green, P.F., Duddy, I.R., Laslett, G.M., Hegarty, K.A., Gleadow, A.J.W., and Lovering, J.F., 1989, Thermal annealing of fission tracks in apatite; 4, Quantitative modeling techniques and extension to geological timescales: Chemical Geology (Isotope Geoscience Section), v. 79, no. 2, p. 155-182.

Larson, J.A., 1988, Paleontology and Biostratigraphy, in Turner, R.F., ed., Geological and operational summary, North Aleutian Shelf COST No. 1 well, Bering Sea, Alaska: U.S. Minerals Management Service, OCS Report MMS 88-0089, p. 159-179.

Laslett, G.M., Green, P.F., Duddy, I.R., and Gleadow, A.J.W., 1987, Thermal modeling of fission tracks in apatite: 2. A quantitative analysis: Chemical Geology, v. 65, p. $1-13$.

Molenaar, C.M., 1996, Thermal-maturity patterns and geothermal gradients on the Alaska Peninsula, in Johnsson, M.J., and Howell, D.G., eds., Thermal evolution of sedimentary basins in Alaska: U.S. Geological Survey Bulletin 2142, p. 11-19.

Murphy J.M., and Clough, J.G., 1999, Low-temperature thermal history using fission track dating in three wells in southern Alaska offshore basins; Lower Cook Inlet,
Shelikof Strait, and Stevenson Trough: Marine Georesources and Geotechnology, v. 17, p. 271-281.

Naeser, C.W., 1979. Fission track dating and geological annealing of fission tracks, in Jager, E. and Hunziker, J.C., eds., Lectures in Isotope Geology: New York, Springer-Verlag, p. 154-169.

Naeser, C.W., 1981. The fading of fission tracks in the geologic environment; Data from deep drill holes: Nuclear Tracks, v. 5, p. 248-250.

Naeser, C.W., and Faul, H., 1969, Fission track annealing in apatite and sphene: Journal of Geophysical Research, v. 74, p. 705-710.

Parker, J., and Newman, R., 1995, Alaska federal offshore; descriptions of geologic plays; 1995 national resource assessment: U.S. Minerals Management Service, North Aleutian Basin Assessment Province http://www. mms.gov/alaska/re/asmtdata/naleutia/naleplay.htm

Paul, T.A., and Fitzgerald, P.G., 1992, Transmission electron microscopic investigation of fission tracks in fluorapatite: American Mineralogist, v. 77, p. 336-344.

Price, P.B., and Walker, R.M., 1963, Fossil tracks of charged particles in gneiss and the age of minerals: Journal of Geophysical Research, v. 68, p. 4,847-4,862.

Scholl, D.W., Vallier, T.L., and Stevenson, A.J., 1986, Terrane accretion, production, and continental growth; A perspective based on the origin and tectonic fate of the Aleutian-Bering Sea region: Geology, v. 14, p. 43-47.

Scholl, D.W., Vallier, T.L., and Stevenson, A.J., 1987, Geologic evolution and petroleum geology of the Aleutian Ridge, in Scholl, D.W., Grantz, Arthur, and Vedder, J.G., eds., Geology and resource potential of the continental margin of western North America and adjacent ocean basins, Beaufort Sea to Baja California: Houston, TX, Circum-Pacific Council For Energy and Mineral Resources, Houston, TX, p. 73-102.

Tagami, T., and O'Sullivan, P.B., 2005, Fundamentals of fission-track thermochronology: Reviews in Mineralogy and Geochemistry, v. 58, p. 19-47.

Turner, R.F., ed., 1988, Geological and operational summary, North Aleutian Shelf COST No. 1 well, Bering Sea, Alaska: U.S. Minerals Management Service, OCS Report MMS 88-0089, 256 p., 2 plates.

Walker, K.T., McGeary, S.E., and Klemperer, S.L., 2003, Tectonic evolution of the Bristol Bay basin, southeast Bering Sea: Constraints from seismic reflection and potential field data: Tectonics, v. 22, no. 5, p. 19

Worrall, D.M., 1991, Tectonic history of the Bering Sea and the evolution of Tertiary strike-slip basins of the Bering Shelf: Geological Society of America Special Paper 257, 120 p., 1 oversize sheet, 4 plates. 
THIS PAGE INTENTIONALLY LEFT BLANK 


\section{APPENDIX 1 ANALYTICAL METHODS}

Core slabs from nine different $5 \mathrm{ft}$ to $29 \mathrm{ft}$ intervals (see table 1), each weighing a total of 2-4 kg, were aggregated, crushed and washed.Apatite and zircon concentrates were prepared in the laboratories of Geochron Inc., Cambridge, MA, using conventional isodynamic magnetic (Frantz barrier separator) and heavy liquid (tetrabromoethane and methylene iodide) techniques. The apatite yields were generally very poor (three samples: NAC4 from 8,644 ft, NAC7 from 12,253 ft, and NAC9 from 16,712 ft lacked workable apatite) to excellent.Many samples contained abundant pyrite.Those splits with excessive pyrite and barite were treated with aqua regia to concentrate zircon.

The external detector method was used for single grain apatite and zircon fission track dating in the laboratories of John Murphy at the University of Wyoming and Shari Kelley at Southern Methodist University Department of Geological Sciences, respectively.Apatite and zircon mounts were covered with low-U muscovite detectors, apatites sandwiched between standards including Durango apatite, NBS glass SRM692, and Corning glass CN-6, and zircons between Fish Canyon and Myalla Road syenite zircon age standards as well as the two glasses.Both packages were irradiated at the Texas A \& M reactor at fluences in the range 6.4-7.0 x $10^{15}$ neutrons $/ \mathrm{cm}^{2}$, and apatites at $0.7-1.4 \times 10^{16}$ neutrons $/ \mathrm{cm}^{2}$. Reactor neutron fluence was calculated using accepted ages of 27.9, 172.8, and 31.4 Ma for Fish Canyon, Myalla Road, and Durango standards and the flux gradient was verified using the glass standards.Muscovite detectors were etched for 13 minutes in 48 percent $\mathrm{HF}$ to reveal induced ${ }^{235} \mathrm{U}$ fission tracks.Individual grain ages were calculated using the zeta correction formulation of Price and Walker (1963); age uncertainty calculations of grains with non-zero ages are those of Hurford and others. (1984). Small fragments of the Durango apatite were mounted with the samples and analyzed as internal standards. The resulting zeta calibration factors for eight grains (assuming an age of $31.4 \mathrm{Ma}$ ) average $352 \pm 45$, compared with the zeta factor for SRM612 of $349 \pm 14$.

Apatite confined track length measurements were made on those samples yielding sufficient quantities of workable apatite using a 100x air objective, digitizing tablet, and a camera-lucida tube.Mounted and polished length mounts were irradiated prior to etching with vertical ${ }^{252} \mathrm{Cf}$ fragments (induced density approximately $10^{6}$ tracks $/ \mathrm{cm}^{2}$ ) at the ARCO Plano fission track laboratory in order to increase the etchable spontaneous confined track yields. The means of spontaneous and induced confined tracks analyzed in the Durango apatite standard concurrent with these analyses were: $14.36 \pm 0.07 \mu \mathrm{m}(1$ sigma $=0.88 \mu \mathrm{m}, \mathrm{n}=150)$ and $16.15 \pm 0.07 \mu \mathrm{m}(1$ sigma $=0.80 \mu \mathrm{m}, \mathrm{n}=150)$, respectively. 


\section{APPENDIX 2 OVERVIEW OF THE FISSION TRACK GEOCHRONOLOGY TECHNIQUE}

Fission track analysis is a geothermochronologic technique for constraining the thermal history of rocks (Fleischer others, 1975; Naeser, 1979; Gleadow others, 1983; Gallagher others, 1998). Detrital grains of apatite and zircon in sedimentary rocks contain minor to trace amounts of ${ }^{238} \mathrm{U}$. Each year, about one in 10 billion ${ }^{238} \mathrm{U}$ atoms decays and one in a million of those undergoes spontaneous fission, or splits into two fragments. Fission tracks are zones of radiation damage in crystals produced by the destructive interaction (creating defects, ionizing atoms, and stripping their electrons) of highly energetic (100-200 Mev), highly charged (>+20e) fission particles (atoms such as $\mathrm{Rb}, \mathrm{Sr}, \mathrm{Ba}, \mathrm{Yb}, \mathrm{Zr}$ ) of variable mass (ca. 85-110, 125-155 amu) (Price and Walker, 1963). Fission tracks are only preserved in dielectric (non-conducting: $>2000 \mathrm{ohm}-\mathrm{cm}$ resistivity) solids (crystals or glasses); conducting solids immediately repair the fragment damage since an abundance of free electrons exist in metals. Although the true identity of fission tracks remains an enigma, recent TEM imaging studies suggest they are probably glassy zones of defects in crystalline matter which are on the order of 50-100 $\AA$ in diameter and $<20 \mu \mathrm{m}$ long in natural oxide minerals such as apatite and zircon (Paul and Fitzgerald, 1992). This damage zone can be enlarged (to $>1-5 \mu \mathrm{m}$ diameter) by etching with a solvent such as nitric acid (apatite) and $\mathrm{NaOH}-\mathrm{KOH}$ (zircon) and studied with an optical microscope.

Since the fission damage zones heal as a function of time and temperature and are rendered unetchable, each mineral possesses a characteristic blocking temperature (usually expressed for a given time scale and cooling rate; Dodson, 1973), above which tracks form but spontaneously anneal, and below which tracks shorten at very slow rates (Naeser, 1979). For rapid cooling rates $\left(30^{\circ} \mathrm{C} / \mathrm{m} . \mathrm{y}\right.$.) and geologic time scales $(1-10 \mathrm{~m} . \mathrm{y}$.$) , the respective$ blocking temperatures for apatite and zircon are approximately $120 \pm 10^{\circ} \mathrm{C}$ and $200 \pm 30^{\circ} \mathrm{C}$ (Naeser, 1979 ; Gleadow others, 1983). Therefore, fission track analysis of apatite and zircon are useful for constraining the low temperature $\left(<200^{\circ} \mathrm{C}\right)$, shallow $(<6 \mathrm{~km})$ thermal history of the upper crust.

Etchable fission tracks in apatite are initially long, ca $16.5 \mu \mathrm{m}$, and shorten by annealing as a function of time and temperature. Apatites that rapidly cool $\left(>10-100^{\circ} \mathrm{C} / \mathrm{m}\right.$.y.) through temperatures $>150^{\circ} \mathrm{C}$ to $<60^{\circ} \mathrm{C}$, possess long tracks $(14-15 \mu \mathrm{m})$, whereas those that experienced a protracted cooling history $\left(<1{ }^{\circ} \mathrm{C} / \mathrm{m} . \mathrm{y}\right.$. $)$ possess shorter tracks $(<13 \mu \mathrm{m})$. Fission tracks in apatite fade and are rendered unetchable if subjected to temperatures $>100$ to $>130^{\circ} \mathrm{C}$ for time scales of 100 to 10 m.y., respectively. The age of a given mineral grain is a function of the fission track density, the length of fission tracks relative to those of the age standard, and uranium concentration. The fissiontrack age in apatite may represent a geologic event, if the apatite cooled rapidly and the tracks are long $(>13.5 \mu \mathrm{m})$, or alternatively some complicated thermal history in the temperature range $60-130^{\circ} \mathrm{C}$, if the apatite cooled slowly and the tracks are short $(<13.5 \mu \mathrm{m})$.

A large body of high temperature $\left(100-400^{\circ} \mathrm{C}\right)$, short term $(<1.5 \mathrm{yr})$ experimental data is available that describes the effect of time and temperature on track shortening and age reduction in apatite (Zimmerman, 1977; Naeser and Faul, 1969, Green others, 1986; Crowley others, 1991). Longer term constraints on track annealing include well documented subsurface samples from wells thought to be at maximum thermal conditions (Naeser, 1981; Gleadow and Duddy, 1981). Kinetic models have been developed by many workers (Crowley, 1985; Laslett others, 1987; Carlson, 1990) that predict the degree of length and age reduction as a function of time and temperature. A compositional effect of annealing kinetics has been recognized by Duddy others (1988) and Green others (1989) and many subsequent workers in which apatites from the Otway Basin with $>1 \mathrm{wt} \% \mathrm{Cl}$ possess higher effective blocking temperatures than F-rich varieties $(<0.4 \mathrm{wt} \% \mathrm{Cl})$. It is thought that $1-3 \mathrm{wt} \% \mathrm{Cl}$ in apatite produces a $10-30^{\circ} \mathrm{C}$ increase in fission track blocking temperature. Alternatively, $\mathrm{Cl}$-rich apatites may possess longer tracks and older ages because they etch at greater rates than Cl-poor varieties. Figure 6 shows the relationship between anion composition and apatite FT age for Mesozoic and Cenozoic samples from five selected wells in the Lower Cook Inlet Alaska. Figure 7 shows that several thousand worldwide apatites from igneous, metamorphic and sedimentary rocks vary widely in anion composition, with a positive correlation between $\mathrm{Cl}$ and $\mathrm{OH}$ and negative correlation between $\mathrm{F}$ and $\mathrm{Cl}$ (Bergman, unpublished data). $\mathrm{As} \mathrm{Cl}$ and $\mathrm{OH}$ are positively correlated, either $\mathrm{OH}$ or $\mathrm{Cl}$ may be the cause of the higher blocking temperatures for those apatites depleted in Fluorine. 


\section{APPENDIX 3 \\ FISSION TRACK DATA TABLES}

94NAC1 Apatite

IRRADIATION WY94-4-1 COUNTED BY: JMM

\begin{tabular}{|c|c|c|c|c|c|c|c|c|c|c|}
\hline No. & Ns & $\mathrm{Ni}$ & $\mathrm{Na}$ & RATIO & $\begin{array}{c}U \\
(\mathrm{ppm})\end{array}$ & RHOS & RHOi & $\begin{array}{l}\text { F.T.AGE } \\
\text { (Ma) }\end{array}$ & & \\
\hline 1 & 16 & 34 & 30 & 0.471 & 10.0 & $8.141 \mathrm{E}+05$ & $1.730 \mathrm{E}+06$ & 151.6 & $+/-$ & 46.1 \\
\hline 2 & 2 & 46 & 64 & 0.043 & 6.3 & $4.770 \mathrm{E}+04$ & $1.097 \mathrm{E}+06$ & 14.2 & $+/-$ & 10.2 \\
\hline 3 & 10 & 106 & 100 & 0.094 & 9.3 & $1.526 \mathrm{E}+05$ & $1.618 \mathrm{E}+06$ & 30.7 & $+/-$ & 10.2 \\
\hline 4 & 12 & 119 & 60 & 0.101 & 17.4 & $3.053 E+05$ & $3.028 \mathrm{E}+06$ & 32.8 & $+/-$ & 10.0 \\
\hline 5 & 9 & 214 & 80 & 0.042 & 23.5 & $1.717 \mathrm{E}+05$ & $4.083 E+06$ & 13.7 & $+/-$ & 4.7 \\
\hline 6 & 2 & 19 & 60 & 0.105 & 2.8 & $5.088 \mathrm{E}+04$ & $4.834 \mathrm{E}+05$ & 34.2 & $+/-$ & 25.5 \\
\hline 7 & 0 & 37 & 100 & 0.000 & 3.3 & $0.000 \mathrm{E}+00$ & $5.648 \mathrm{E}+05$ & 0.0 & $+/-$ & 0.0 \\
\hline 8 & 24 & 310 & 70 & 0.077 & 38.9 & $5.234 \mathrm{E}+05$ & $6.760 \mathrm{E}+06$ & 25.2 & $+/-$ & 5.4 \\
\hline 9 & 60 & 267 & 100 & 0.225 & 23.5 & $9.159 \mathrm{E}+05$ & $4.076 \mathrm{E}+06$ & 72.9 & $+/-$ & 10.5 \\
\hline 10 & 18 & 285 & 100 & 0.063 & 25.0 & $2.748 \mathrm{E}+05$ & $4.350 \mathrm{E}+06$ & 20.6 & $+/-$ & 5.0 \\
\hline 11 & 6 & 99 & 50 & 0.061 & 17.4 & $1.832 \mathrm{E}+05$ & $3.022 \mathrm{E}+06$ & 19.7 & $+/-$ & 8.3 \\
\hline 12 & 16 & 221 & 80 & 0.072 & 24.3 & $3.053 \mathrm{E}+05$ & $4.217 \mathrm{E}+06$ & 23.6 & $+/-$ & 6.1 \\
\hline 13 & 16 & 221 & 100 & 0.072 & 19.4 & $2.442 \mathrm{E}+05$ & $3.374 \mathrm{E}+06$ & 23.6 & $+/-$ & 6.1 \\
\hline 14 & 7 & 195 & 60 & 0.036 & 28.6 & $1.781 \mathrm{E}+05$ & $4.961 E+06$ & 11.7 & $+/-$ & 4.5 \\
\hline 15 & 31 & 319 & 70 & 0.097 & 40.0 & $6.760 \mathrm{E}+05$ & $6.956 \mathrm{E}+06$ & 31.6 & $+/-$ & 6.0 \\
\hline 16 & 23 & 453 & 100 & 0.051 & 39.8 & $3.511 E+05$ & $6.915 \mathrm{E}+06$ & 16.5 & $+/-$ & 3.6 \\
\hline 17 & 20 & 217 & 50 & 0.092 & 38.1 & $6.106 \mathrm{E}+05$ & $6.625 E+06$ & 30.0 & $+/-$ & 7.0 \\
\hline 18 & 23 & 322 & 50 & 0.071 & 56.6 & $7.022 \mathrm{E}+05$ & $9.831 \mathrm{E}+06$ & 23.2 & $+/-$ & 5.0 \\
\hline 19 & 20 & 290 & 100 & 0.069 & 25.5 & $3.053 \mathrm{E}+05$ & $4.427 \mathrm{E}+06$ & 22.4 & $+/-$ & 5.2 \\
\hline 20 & 18 & 213 & 49 & 0.084 & 38.2 & $5.607 \mathrm{E}+05$ & $6.636 \mathrm{E}+06$ & 27.5 & $+/-$ & 6.8 \\
\hline 21 & 10 & 86 & 100 & 0.116 & 7.6 & $1.526 \mathrm{E}+05$ & $1.313 \mathrm{E}+06$ & 37.8 & $+/-$ & 12.7 \\
\hline 22 & 64 & 409 & 100 & 0.156 & 35.9 & $9.770 \mathrm{E}+05$ & $6.243 \mathrm{E}+06$ & 50.8 & $+/-$ & 6.9 \\
\hline 23 & 29 & 105 & 30 & 0.276 & 30.8 & $1.476 \mathrm{E}+06$ & $5.343 \mathrm{E}+06$ & 89.4 & $+/-$ & 18.9 \\
\hline 24 & 37 & 462 & 60 & 0.080 & 67.7 & $9.413 \mathrm{E}+05$ & $1.175 \mathrm{E}+07$ & 26.1 & $+/-$ & 4.5 \\
\hline 25 & 8 & 195 & 30 & 0.041 & 57.1 & $4.071 E+05$ & $9.922 \mathrm{E}+06$ & 13.4 & $+/-$ & 4.8 \\
\hline 26 & 5 & 61 & 40 & 0.082 & 13.4 & $1.908 \mathrm{E}+05$ & $2.328 \mathrm{E}+06$ & 26.7 & $+/-$ & 12.4 \\
\hline 27 & 33 & 895 & 100 & 0.037 & 78.6 & $5.037 \mathrm{E}+05$ & $1.366 \mathrm{E}+07$ & 12.0 & $+/-$ & 2.1 \\
\hline 28 & 2 & 81 & 80 & 0.025 & 8.9 & $3.816 \mathrm{E}+04$ & $1.546 \mathrm{E}+06$ & 8.0 & $+/-$ & 5.8 \\
\hline 29 & 5 & 103 & 60 & 0.049 & 15.1 & $1.272 \mathrm{E}+05$ & $2.620 \mathrm{E}+06$ & 15.8 & $+/-$ & 7.2 \\
\hline 30 & 26 & 108 & 100 & 0.241 & 9.5 & $3.969 \mathrm{E}+05$ & $1.649 \mathrm{E}+06$ & 78.0 & $+/-$ & 17.1 \\
\hline \multirow[t]{2}{*}{31} & 62 & 862 & 90 & 0.072 & 84.2 & $1.052 \mathrm{E}+06$ & $1.462 \mathrm{E}+07$ & 23.4 & $+/-$ & 3.1 \\
\hline & 614 & 7354 & & & 28.6 & $4.142 \mathrm{E}+05$ & $4.961 E+06$ & & & \\
\hline
\end{tabular}

Area of basic unit $=6.551 \mathrm{E}-07 \mathrm{~cm}-2$

CHI SQUARED $=118.0924$ WITH 30 DEGREES OF FREEDOM

$\mathrm{P}($ chi squared $)=0.0 \%$

CORRELATION COEFFICIENT $=0.687$

VARIANCE OF SQR(Ns) $=3.706818$

VARIANCE OF SQR $(\mathrm{Ni})=38.24873$

$\mathrm{Ns} / \mathrm{Ni}=0.083+/-0.004$

MEAN RATIO $=0.100+/-0.017$

Pooled Age $=27.2+/-1.3 \mathrm{Ma}$

Mean Age $=32.6+/-5.4 \mathrm{Ma}$

Central Age $=30.1+/-4.0 \mathrm{Ma}$

$\%$ Variation $=67.85 \%$

Ages calculated using a zeta of $12250+/-1000$ for SRM963a glass

$\mathrm{RHO} D=5.323 \mathrm{E}+04 \mathrm{~cm}-2 ; \mathrm{ND}=2561$ 
94NAC2 Apatite

IRRADIATION WY94-4-2 COUNTED BY: JMM

\begin{tabular}{|c|c|c|c|c|c|c|c|c|c|c|}
\hline No. & Ns & $\mathrm{Ni}$ & $\mathrm{Na}$ & RATIO & $\underset{(p p m)}{U}$ & RHOS & RHOi & $\begin{array}{l}\text { F.T.AGE } \\
\text { (Ma) }\end{array}$ & & \\
\hline 1 & 40 & 348 & 60 & 0.115 & 51.4 & $1.018 \mathrm{E}+06$ & $8.854 \mathrm{E}+06$ & 37.0 & $+1-$ & 6.2 \\
\hline 2 & 15 & 55 & 30 & 0.273 & 16.3 & $7.632 \mathrm{E}+05$ & $2.799 \mathrm{E}+06$ & 87.5 & $+1-$ & 25.6 \\
\hline 3 & 7 & 84 & 24 & 0.083 & 31.0 & $4.452 \mathrm{E}+05$ & $5.343 \mathrm{E}+06$ & 26.9 & $+1-$ & 10.6 \\
\hline 4 & 5 & 104 & 48 & 0.048 & 19.2 & $1.590 \mathrm{E}+05$ & $3.307 \mathrm{E}+06$ & 15.5 & $+/-$ & 7.1 \\
\hline 5 & 1 & 32 & 100 & 0.031 & 2.8 & $1.526 \mathrm{E}+04$ & $4.885 \mathrm{E}+05$ & 10.1 & $+1-$ & 10.2 \\
\hline 6 & 33 & 402 & 60 & 0.082 & 59.4 & $8.396 \mathrm{E}+05$ & $1.023 \mathrm{E}+07$ & 26.5 & $+1-$ & 4.8 \\
\hline 7 & 25 & 528 & 100 & 0.047 & 46.8 & $3.816 \mathrm{E}+05$ & $8.060 \mathrm{E}+06$ & 15.3 & $+1-$ & 3.1 \\
\hline 8 & 15 & 137 & 64 & 0.109 & 19.0 & $3.578 \mathrm{E}+05$ & $3.268 \mathrm{E}+06$ & 35.3 & $+/-$ & 9.6 \\
\hline 9 & 2 & 25 & 100 & 0.080 & 2.2 & $3.053 \mathrm{E}+04$ & $3.816 \mathrm{E}+05$ & 25.8 & $+1-$ & 19.0 \\
\hline 10 & 2 & 23 & 70 & 0.087 & 2.9 & $4.361 \mathrm{E}+04$ & $5.016 \mathrm{E}+05$ & 28.0 & $+1-$ & 20.7 \\
\hline 11 & 5 & 297 & 50 & 0.017 & 52.7 & $1.526 \mathrm{E}+05$ & $9.067 \mathrm{E}+06$ & 5.4 & $+/-$ & 2.5 \\
\hline 12 & 9 & 21 & 100 & 0.429 & 1.9 & $1.374 \mathrm{E}+05$ & $3.206 \mathrm{E}+05$ & 137.0 & $+1-$ & 54.7 \\
\hline 13 & 4 & 35 & 100 & 0.114 & 3.1 & $6.106 \mathrm{E}+04$ & $5.343 \mathrm{E}+05$ & 36.8 & $+1-$ & 19.5 \\
\hline 14 & 37 & 328 & 50 & 0.113 & 58.2 & $1.130 \mathrm{E}+06$ & $1.001 \mathrm{E}+07$ & 36.4 & $+/-$ & 6.4 \\
\hline 15 & 20 & 191 & 100 & 0.105 & 16.9 & $3.053 \mathrm{E}+05$ & $2.916 \mathrm{E}+06$ & 33.7 & $+/-$ & 8.0 \\
\hline 16 & 12 & 67 & 100 & 0.179 & 5.9 & $1.832 \mathrm{E}+05$ & $1.023 \mathrm{E}+06$ & 57.6 & $+1-$ & 18.1 \\
\hline 17 & 10 & 175 & 49 & 0.057 & 31.7 & $3.115 \mathrm{E}+05$ & $5.452 \mathrm{E}+06$ & 18.4 & $+1-$ & 6.0 \\
\hline 18 & 10 & 110 & 42 & 0.091 & 23.2 & $3.634 \mathrm{E}+05$ & $3.998 \mathrm{E}+06$ & 29.3 & $+1-$ & 9.7 \\
\hline 19 & 16 & 148 & 70 & 0.108 & 18.7 & $3.489 \mathrm{E}+05$ & $3.227 \mathrm{E}+06$ & 34.8 & $+1-$ & 9.2 \\
\hline 20 & 17 & 138 & 70 & 0.123 & 17.5 & $3.707 \mathrm{E}+05$ & $3.009 \mathrm{E}+06$ & 39.7 & $+/-$ & 10.2 \\
\hline 21 & 5 & 29 & 100 & 0.172 & 2.6 & $7.632 \mathrm{E}+04$ & $4.427 \mathrm{E}+05$ & 55.5 & $+/-$ & 26.9 \\
\hline 22 & 10 & 79 & 50 & 0.127 & 14.0 & $3.053 \mathrm{E}+05$ & $2.412 \mathrm{E}+06$ & 40.8 & $+/-$ & 13.7 \\
\hline 23 & 17 & 141 & 100 & 0.121 & 12.5 & $2.595 \mathrm{E}+05$ & $2.152 \mathrm{E}+06$ & 38.8 & $+/-$ & 10.0 \\
\hline 24 & 10 & 155 & 100 & 0.065 & 13.7 & $1.526 \mathrm{E}+05$ & $2.366 \mathrm{E}+06$ & 20.8 & $+/-$ & 6.8 \\
\hline 25 & 13 & 213 & 100 & 0.061 & 18.9 & 1.984E+05 & $3.251 \mathrm{E}+06$ & 19.7 & $+1-$ & 5.6 \\
\hline 26 & 34 & 307 & 36 & 0.111 & 75.6 & $1.442 \mathrm{E}+06$ & $1.302 \mathrm{E}+07$ & 35.7 & $+1-$ & 6.5 \\
\hline 27 & 6 & 65 & 100 & 0.092 & 5.8 & $9.159 \mathrm{E}+04$ & $9.922 \mathrm{E}+05$ & 29.8 & $+/-$ & 12.7 \\
\hline 28 & 10 & 108 & 49 & 0.093 & 19.5 & $3.115 \mathrm{E}+05$ & $3.364 \mathrm{E}+06$ & 29.9 & $+1-$ & 9.9 \\
\hline 29 & 25 & 119 & 25 & 0.210 & 42.2 & $1.526 \mathrm{E}+06$ & $7.266 \mathrm{E}+06$ & 67.5 & $+1-$ & 14.9 \\
\hline 30 & 14 & 229 & 100 & 0.061 & 20.3 & $2.137 \mathrm{E}+05$ & $3.496 \mathrm{E}+06$ & 19.7 & $+1-$ & 5.4 \\
\hline \multirow[t]{2}{*}{31} & 25 & 308 & 100 & 0.081 & 27.3 & $3.816 \mathrm{E}+05$ & $4.702 \mathrm{E}+06$ & 26.2 & $+1-$ & 5.5 \\
\hline & 454 & 5001 & & & 19.7 & $3.084 E+05$ & $3.397 \mathrm{E}+06$ & & & \\
\hline
\end{tabular}

Area of basic unit $=6.551 \mathrm{E}-07 \mathrm{~cm}-2$

CHI SQUARED $=52.7205$ WITH 30 DEGREES OF FREEDOM

$P($ chi squared $)=0.0 \%$

CORRELATION COEFFICIENT $=0.758$

VARIANCE OF SQR(Ns) $=1.956051$

VARIANCE OF SQR(Ni) $=24.34258$

$\mathrm{Ns} / \mathrm{Ni}=0.091+/-0.004$

MEAN RATIO $=0.112+/-0.014$

Pooled Age = 29.3+/- 1.6 Ma

Mean Age $=36.2+/-4.6 \mathrm{Ma}$

Central Age $=32.4+/-3.1 \mathrm{Ma}$

$\%$ Variation $=40.65 \%$

Ages calculated using a zeta of $12250+/-1000$ for SRM963a glass

$\mathrm{RHO} D=5.276 \mathrm{E}+04 \mathrm{~cm}-2 ; \mathrm{ND}=2561$ 
94NAC3 Apatite

IRRADIATION WY94-4-3 COUNTED BY: JMM

\begin{tabular}{|c|c|c|c|c|c|c|c|c|c|c|}
\hline $\begin{array}{l}\mathrm{N} \\
\mathrm{O} .\end{array}$ & Ns & $\mathrm{Ni}$ & $\mathrm{Na}$ & RATIO & $\underset{(\mathrm{ppm})}{\mathbf{U}}$ & RHOS & RHOi & $\begin{array}{c}\text { F.T.AGE } \\
\text { (Ma) }\end{array}$ & & \\
\hline 1 & 29 & 86 & 49 & 0.337 & 15.7 & $9.034 \mathrm{E}+05$ & $2.679 \mathrm{E}+06$ & 107.1 & $+/-$ & 24.7 \\
\hline 2 & 2 & 5 & 64 & 0.400 & 0.7 & $4.770 \mathrm{E}+04$ & $1.193 E+05$ & 126.9 & $+/-$ & 106.7 \\
\hline 3 & 13 & 89 & 15 & 0.146 & 53.1 & $1.323 \mathrm{E}+06$ & $9.057 \mathrm{E}+06$ & 46.6 & $+/-$ & 14.4 \\
\hline 4 & 1 & 6 & 36 & 0.167 & 1.5 & $4.240 \mathrm{E}+04$ & $2.544 \mathrm{E}+05$ & 53.2 & $+/-$ & 57.6 \\
\hline 5 & 11 & 76 & 25 & 0.145 & 27.2 & $6.717 \mathrm{E}+05$ & $4.641 \mathrm{E}+06$ & 46.2 & $+/-$ & 15.4 \\
\hline 6 & 89 & 306 & 70 & 0.291 & 39.1 & $1.941 \mathrm{E}+06$ & $6.673 \mathrm{E}+06$ & 92.5 & $+/-$ & 13.6 \\
\hline 7 & 6 & 52 & 16 & 0.115 & 29.1 & $5.724 \mathrm{E}+05$ & $4.961 \mathrm{E}+06$ & 36.8 & $+/-$ & 16.2 \\
\hline 8 & 17 & 55 & 50 & 0.309 & 9.8 & $5.190 \mathrm{E}+05$ & $1.679 \mathrm{E}+06$ & 98.2 & $+/-$ & 28.5 \\
\hline 9 & 7 & 20 & 70 & 0.350 & 2.6 & $1.526 \mathrm{E}+05$ & $4.361 \mathrm{E}+05$ & 111.1 & $+/-$ & 49.7 \\
\hline 10 & 5 & 22 & 20 & 0.227 & 9.8 & $3.816 \mathrm{E}+05$ & $1.679 \mathrm{E}+06$ & 72.4 & $+/-$ & 36.4 \\
\hline 11 & 1 & 4 & 20 & 0.250 & 1.8 & $7.632 \mathrm{E}+04$ & $3.053 \mathrm{E}+05$ & 79.6 & $+/-$ & 89.2 \\
\hline 12 & 5 & 23 & 40 & 0.217 & 5.1 & $1.908 \mathrm{E}+05$ & $8.777 \mathrm{E}+05$ & 69.3 & $+/-$ & 34.7 \\
\hline 13 & 5 & 12 & 60 & 0.417 & 1.8 & $1.272 \mathrm{E}+05$ & $3.053 \mathrm{E}+05$ & 132.1 & $+/-$ & 71.2 \\
\hline 14 & 26 & 111 & 24 & 0.234 & 41.4 & $1.654 \mathrm{E}+06$ & $7.060 \mathrm{E}+06$ & 74.6 & $+/-$ & 17.4 \\
\hline 15 & 11 & 219 & 27 & 0.050 & 72.6 & $6.219 \mathrm{E}+05$ & $1.238 \mathrm{E}+07$ & 16.1 & $+/-$ & 5.1 \\
\hline 16 & 30 & 99 & 50 & 0.303 & 17.7 & $9.159 E+05$ & $3.022 \mathrm{E}+06$ & 96.3 & $+/-$ & 21.6 \\
\hline 17 & 3 & 59 & 28 & 0.051 & 18.8 & $1.636 \mathrm{E}+05$ & $3.217 \mathrm{E}+06$ & 16.3 & $+/-$ & 9.7 \\
\hline 18 & 9 & 39 & 15 & 0.231 & 23.3 & $9.159 \mathrm{E}+05$ & $3.969 \mathrm{E}+06$ & 73.5 & $+/-$ & 27.9 \\
\hline 19 & 10 & 21 & 24 & 0.476 & 7.8 & $6.360 \mathrm{E}+05$ & $1.336 \mathrm{E}+06$ & 150.7 & $+/-$ & 59.3 \\
\hline 20 & 4 & 24 & 50 & 0.167 & 4.3 & $1.221 \mathrm{E}+05$ & 7.327E+05 & 53.2 & $+/-$ & 29.1 \\
\hline 21 & 45 & 172 & 64 & 0.262 & 24.0 & $1.073 \mathrm{E}+06$ & $4.102 \mathrm{E}+06$ & 83.3 & $+/-$ & 15.6 \\
\hline 22 & 15 & 52 & 60 & 0.288 & 7.8 & $3.816 \mathrm{E}+05$ & $1.323 \mathrm{E}+06$ & 91.7 & $+/-$ & 28.0 \\
\hline 23 & 7 & 22 & 28 & 0.318 & 7.0 & $3.816 \mathrm{E}+05$ & $1.199 \mathrm{E}+06$ & 101.1 & $+/-$ & 44.7 \\
\hline 24 & 14 & 51 & 21 & 0.274 & 21.7 & $1.018 \mathrm{E}+06$ & $3.707 \mathrm{E}+06$ & 87.3 & $+/-$ & 27.3 \\
\hline 25 & 23 & 56 & 9 & 0.411 & 55.7 & $3.901 \mathrm{E}+06$ & $9.498 \mathrm{E}+06$ & 130.2 & $+/-$ & 34.1 \\
\hline 26 & 6 & 32 & 64 & 0.188 & 4.5 & $1.431 \mathrm{E}+05$ & $7.632 \mathrm{E}+05$ & 59.8 & $+/-$ & 27.1 \\
\hline 27 & 9 & 58 & 21 & 0.155 & 24.7 & $6.542 \mathrm{E}+05$ & $4.216 \mathrm{E}+06$ & 49.5 & $+/-$ & 18.2 \\
\hline 28 & 17 & 294 & 70 & 0.058 & 37.6 & 3.707E+05 & $6.411 \mathrm{E}+06$ & 18.5 & $+/-$ & 4.9 \\
\hline 29 & 30 & 67 & 100 & 0.448 & 6.0 & $4.579 \mathrm{E}+05$ & $1.023 \mathrm{E}+06$ & 141.8 & $+/-$ & 33.4 \\
\hline 30 & 12 & 34 & 100 & 0.353 & 3.0 & 1.832E+05 & $5.190 \mathrm{E}+05$ & 112.1 & $+/-$ & 38.8 \\
\hline \multirow[t]{2}{*}{31} & 4 & 24 & 50 & 0.167 & 4.3 & $1.221 \mathrm{E}+05$ & 7.327E+05 & 53.2 & $+/-$ & 29.1 \\
\hline & 466 & 2190 & & & 14.6 & $5.309 \mathrm{E}+05$ & $2.495 E+06$ & & & \\
\hline
\end{tabular}

Area of basic unit $=6.551 \mathrm{E}-07 \mathrm{~cm}-2$

CHI SQUARED $=60.58839$ WITH 30 DEGREES OF FREEDOM

$\mathrm{P}($ chi squared $)=0.0 \%$

CORRELATION COEFFICIENT $=0.714$

VARIANCE OF SQR(NS) $=3.188586$

VARIANCE OF SQR(Ni) $=15.46305$

$\mathrm{Ns} / \mathrm{Ni}=0.213+/-0.011$

MEAN RATIO $=0.252+/-0.021$

Pooled Age $=67.8+/-6.7 \mathrm{Ma}$

Mean Age $=80.1+/-9.4 \mathrm{Ma}$

Central Age $=73.8+/-7.4 \mathrm{Ma}$

$\%$ Variation $=41.81 \%$

Ages calculated using a zeta of $12250+/-1000$ for SRM963a glass

$\mathrm{RHO} D=5.229 \mathrm{E}+04 \mathrm{~cm}-2 ; \mathrm{ND}=2561$ 
94NAC5 Apatite

IRRADIATION WY94-4-4 COUNTED BY: JMM

\begin{tabular}{|c|c|c|c|c|c|c|c|c|c|c|}
\hline No. & Ns & $\mathrm{Ni}$ & $\mathrm{Na}$ & RATIO & $\underset{(p p m)}{U}$ & RHOS & RHOi & $\begin{array}{c}\text { F.T.AGE } \\
(\mathrm{Ma})\end{array}$ & & \\
\hline 1 & 6 & 46 & 100 & 0.130 & 4.2 & $9.159 \mathrm{E}+04$ & $7.022 \mathrm{E}+05$ & 41.3 & $+/-$ & 18.2 \\
\hline 2 & 6 & 50 & 100 & 0.120 & 4.5 & $9.159 \mathrm{E}+04$ & $7.632 \mathrm{E}+05$ & 38.0 & $+/-$ & 16.7 \\
\hline 3 & 7 & 58 & 100 & 0.121 & 5.2 & $1.069 \mathrm{E}+05$ & $8.854 \mathrm{E}+05$ & 38.2 & $+/-$ & 15.6 \\
\hline 4 & 3 & 21 & 60 & 0.143 & 3.2 & $7.632 \mathrm{E}+04$ & $5.343 \mathrm{E}+05$ & 45.2 & $+/-$ & 28.1 \\
\hline 5 & 7 & 73 & 100 & 0.096 & 6.6 & $1.069 \mathrm{E}+05$ & $1.114 \mathrm{E}+06$ & 30.4 & $+/-$ & 12.3 \\
\hline 6 & 8 & 45 & 100 & 0.178 & 4.1 & $1.221 \mathrm{E}+05$ & $6.869 \mathrm{E}+05$ & 56.2 & $+/-$ & 22.1 \\
\hline 7 & 15 & 69 & 40 & 0.217 & 15.6 & $5.724 \mathrm{E}+05$ & $2.633 \mathrm{E}+06$ & 68.6 & $+/-$ & 20.4 \\
\hline 8 & 5 & 25 & 100 & 0.200 & 2.3 & $7.632 \mathrm{E}+04$ & $3.816 \mathrm{E}+05$ & 63.2 & $+/-$ & 31.4 \\
\hline 9 & 7 & 74 & 100 & 0.095 & 6.7 & $1.069 \mathrm{E}+05$ & $1.130 \mathrm{E}+06$ & 29.9 & $+/-$ & 12.1 \\
\hline 10 & 12 & 99 & 80 & 0.121 & 11.2 & $2.290 \mathrm{E}+05$ & $1.889 \mathrm{E}+06$ & 38.4 & $+/-$ & 12.2 \\
\hline 11 & 6 & 67 & 100 & 0.090 & 6.0 & $9.159 \mathrm{E}+04$ & $1.023 \mathrm{E}+06$ & 28.4 & $+/-$ & 12.3 \\
\hline 12 & 9 & 62 & 80 & 0.145 & 7.0 & 1.717E+05 & $1.183 \mathrm{E}+06$ & 45.9 & $+/-$ & 16.8 \\
\hline 13 & 12 & 79 & 100 & 0.152 & 7.1 & $1.832 \mathrm{E}+05$ & $1.206 \mathrm{E}+06$ & 48.0 & $+/-$ & 15.4 \\
\hline 14 & 7 & 87 & 100 & 0.080 & 7.9 & $1.069 \mathrm{E}+05$ & $1.328 \mathrm{E}+06$ & 25.5 & $+/-$ & 10.2 \\
\hline 15 & 3 & 38 & 100 & 0.079 & 3.4 & $4.579 \mathrm{E}+04$ & $5.801 \mathrm{E}+05$ & 25.0 & $+/-$ & 15.1 \\
\hline 16 & 7 & 86 & 100 & 0.081 & 7.8 & $1.069 \mathrm{E}+05$ & $1.313 \mathrm{E}+06$ & 25.8 & $+/-$ & 10.4 \\
\hline 17 & 9 & 67 & 100 & 0.134 & 6.0 & $1.374 \mathrm{E}+05$ & $1.023 \mathrm{E}+06$ & 42.5 & $+/-$ & 15.5 \\
\hline 18 & 10 & 93 & 100 & 0.108 & 8.4 & $1.526 \mathrm{E}+05$ & $1.420 \mathrm{E}+06$ & 34.0 & $+/-$ & 11.7 \\
\hline 19 & 10 & 87 & 100 & 0.115 & 7.9 & $1.526 \mathrm{E}+05$ & $1.328 \mathrm{E}+06$ & 36.4 & $+/-$ & 12.5 \\
\hline 20 & 11 & 97 & 100 & 0.113 & 8.8 & $1.679 \mathrm{E}+05$ & $1.481 \mathrm{E}+06$ & 35.9 & $+/-$ & 11.8 \\
\hline 21 & 15 & 87 & 100 & 0.172 & 7.9 & $2.290 \mathrm{E}+05$ & $1.328 \mathrm{E}+06$ & 54.5 & $+/-$ & 15.9 \\
\hline 22 & 12 & 108 & 100 & 0.111 & 9.7 & $1.832 \mathrm{E}+05$ & $1.649 \mathrm{E}+06$ & 35.2 & $+/-$ & 11.1 \\
\hline 23 & 5 & 84 & 100 & 0.060 & 7.6 & $7.632 \mathrm{E}+04$ & $1.282 \mathrm{E}+06$ & 18.9 & $+/-$ & 8.8 \\
\hline 24 & 5 & 57 & 100 & 0.088 & 5.1 & $7.632 \mathrm{E}+04$ & $8.701 \mathrm{E}+05$ & 27.8 & $+/-$ & 13.2 \\
\hline 25 & 11 & 173 & 100 & 0.064 & 15.6 & $1.679 \mathrm{E}+05$ & $2.641 \mathrm{E}+06$ & 20.1 & $+/-$ & 6.5 \\
\hline 26 & 8 & 69 & 100 & 0.116 & 6.2 & $1.221 \mathrm{E}+05$ & $1.053 \mathrm{E}+06$ & 36.7 & $+/-$ & 14.0 \\
\hline 27 & 15 & 89 & 49 & 0.169 & 16.4 & $4.673 \mathrm{E}+05$ & $2.773 \mathrm{E}+06$ & 53.3 & $+/-$ & 15.5 \\
\hline 28 & 6 & 87 & 100 & 0.069 & 7.9 & $9.159 \mathrm{E}+04$ & $1.328 \mathrm{E}+06$ & 21.8 & $+/-$ & 9.4 \\
\hline 29 & 5 & 62 & 100 & 0.081 & 5.6 & $7.632 \mathrm{E}+04$ & $9.464 \mathrm{E}+05$ & 25.5 & $+/-$ & 12.1 \\
\hline 30 & 6 & 100 & 100 & 0.060 & 9.0 & $9.159 \mathrm{E}+04$ & $1.526 \mathrm{E}+06$ & 19.0 & $+/-$ & 8.1 \\
\hline \multirow[t]{2}{*}{31} & 7 & 81 & 100 & 0.086 & 7.3 & $1.069 \mathrm{E}+05$ & $1.236 \mathrm{E}+06$ & 27.4 & $+/-$ & 11.0 \\
\hline & 255 & 2320 & & & 7.2 & $1.338 \mathrm{E}+05$ & 1.217E+06 & & & \\
\hline
\end{tabular}

Area of basic unit $=6.551 \mathrm{E}-07 \mathrm{~cm}-2$

CHI SQUARED $=14.10372$ WITH 30 DEGREES OF FREEDOM

$P($ chi squared $)=55.9 \%$

CORRELATION COEFFICIENT $=0.529$

VARIANCE OF SQR(NS) $=.3320277$

VARIANCE OF SQR $(\mathrm{Ni})=2.725667$

$\mathrm{Ns} / \mathrm{Ni}=0.110+/-0.007$

MEAN RATIO $=0.116+/-0.007$

Pooled Age $=34.8+/-3.7 \mathrm{Ma}$

Mean Age $=36.7+/-3.9 \mathrm{Ma}$

Central Age $=34.9+/-2.5 \mathrm{Ma}$

$\%$ Variation $=7.98 \%$

Ages calculated using a zeta of $12250+/-1000$ for SRM963a glass

$\mathrm{RHO} D=5.181 \mathrm{E}+04 \mathrm{~cm}-2 ; \mathrm{ND}=2561$ 
94NAC6 Apatite

IRRADIATION WY94-4-5 COUNTED BY: JMM

\begin{tabular}{|c|c|c|c|c|c|c|c|c|c|c|}
\hline No. & Ns & $\mathrm{Ni}$ & $\mathrm{Na}$ & RATIO & $\begin{array}{c}U \\
(\mathrm{ppm})\end{array}$ & RHOS & RHOi & $\begin{array}{l}\text { F.T.AGE } \\
(\mathrm{Ma})\end{array}$ & & \\
\hline 1 & 3 & 10 & 100 & 0.300 & 0.9 & $4.579 \mathrm{E}+04$ & $1.526 \mathrm{E}+05$ & 93.7 & $+/-$ & 62.1 \\
\hline 2 & 7 & 19 & 100 & 0.368 & 1.7 & $1.069 \mathrm{E}+05$ & $2.900 \mathrm{E}+05$ & 114.8 & $+/-$ & 51.7 \\
\hline 3 & 6 & 40 & 49 & 0.150 & 7.4 & $1.869 \mathrm{E}+05$ & $1.246 \mathrm{E}+06$ & 47.0 & $+/-$ & 21.0 \\
\hline 4 & 3 & 8 & 36 & 0.375 & 2.0 & $1.272 \mathrm{E}+05$ & $3.392 \mathrm{E}+05$ & 116.9 & $+/-$ & 79.7 \\
\hline 5 & 2 & 9 & 30 & 0.222 & 2.7 & $1.018 \mathrm{E}+05$ & $4.579 \mathrm{E}+05$ & 69.5 & $+/-$ & 54.6 \\
\hline 6 & 2 & 10 & 100 & 0.200 & 0.9 & $3.053 \mathrm{E}+04$ & $1.526 \mathrm{E}+05$ & 62.6 & $+/-$ & 48.8 \\
\hline 7 & 3 & 28 & 100 & 0.107 & 2.6 & $4.579 \mathrm{E}+04$ & $4.274 \mathrm{E}+05$ & 33.6 & $+/-$ & 20.6 \\
\hline 8 & 4 & 21 & 100 & 0.190 & 1.9 & $6.106 \mathrm{E}+04$ & $3.206 \mathrm{E}+05$ & 59.6 & $+/-$ & 32.9 \\
\hline 9 & 3 & 8 & 50 & 0.375 & 1.5 & $9.159 \mathrm{E}+04$ & $2.442 \mathrm{E}+05$ & 116.9 & $+/-$ & 79.7 \\
\hline 10 & 1 & 17 & 100 & 0.059 & 1.5 & $1.526 \mathrm{E}+04$ & $2.595 \mathrm{E}+05$ & 18.5 & $+/-$ & 19.1 \\
\hline 11 & 6 & 27 & 100 & 0.222 & 2.5 & $9.159 \mathrm{E}+04$ & $4.122 \mathrm{E}+05$ & 69.5 & $+/-$ & 31.9 \\
\hline 12 & 3 & 20 & 70 & 0.150 & 2.6 & $6.542 \mathrm{E}+04$ & $4.361 \mathrm{E}+05$ & 47.0 & $+/-$ & 29.4 \\
\hline 13 & 7 & 44 & 60 & 0.159 & 6.7 & $1.781 \mathrm{E}+05$ & $1.119 \mathrm{E}+06$ & 49.8 & $+/-$ & 20.7 \\
\hline 14 & 4 & 29 & 70 & 0.138 & 3.8 & $8.723 \mathrm{E}+04$ & $6.324 \mathrm{E}+05$ & 43.2 & $+/-$ & 23.3 \\
\hline 15 & 2 & 24 & 70 & 0.083 & 3.1 & $4.361 \mathrm{E}+04$ & $5.234 \mathrm{E}+05$ & 26.2 & $+/-$ & 19.4 \\
\hline 16 & 8 & 75 & 70 & 0.107 & 9.8 & $1.745 E+05$ & $1.636 \mathrm{E}+06$ & 33.5 & $+/-$ & 12.8 \\
\hline 17 & 4 & 24 & 80 & 0.167 & 2.7 & $7.632 \mathrm{E}+04$ & $4.579 \mathrm{E}+05$ & 52.2 & $+/-$ & 28.5 \\
\hline 18 & 7 & 50 & 50 & 0.140 & 9.1 & $2.137 \mathrm{E}+05$ & $1.526 \mathrm{E}+06$ & 43.9 & $+/-$ & 18.1 \\
\hline 19 & 4 & 29 & 49 & 0.138 & 5.4 & $1.246 \mathrm{E}+05$ & $9.034 \mathrm{E}+05$ & 43.2 & $+/-$ & 23.3 \\
\hline 20 & 2 & 11 & 40 & 0.182 & 2.5 & $7.632 \mathrm{E}+04$ & $4.198 \mathrm{E}+05$ & 56.9 & $+/-$ & 44.0 \\
\hline 21 & 1 & 6 & 40 & 0.167 & 1.4 & $3.816 \mathrm{E}+04$ & $2.290 \mathrm{E}+05$ & 52.2 & $+/-$ & 56.6 \\
\hline 22 & 3 & 23 & 60 & 0.130 & 3.5 & $7.632 \mathrm{E}+04$ & $5.852 \mathrm{E}+05$ & 40.9 & $+/-$ & 25.3 \\
\hline 23 & 0 & 4 & 30 & 0.000 & 1.2 & $0.000 \mathrm{E}+00$ & $2.035 E+05$ & 0.0 & $+/-$ & 0.0 \\
\hline 24 & 2 & 14 & 49 & 0.143 & 2.6 & $6.231 \mathrm{E}+04$ & $4.361 \mathrm{E}+05$ & 44.8 & $+/-$ & 34.0 \\
\hline 25 & 2 & 17 & 80 & 0.118 & 1.9 & $3.816 \mathrm{E}+04$ & $3.244 \mathrm{E}+05$ & 36.9 & $+/-$ & 27.7 \\
\hline \multirow[t]{2}{*}{26} & 7 & 36 & 56 & 0.194 & 5.9 & $1.908 \mathrm{E}+05$ & $9.813 \mathrm{E}+05$ & 60.9 & $+/-$ & 25.7 \\
\hline & 96 & 603 & & & 3.2 & 8.427E+04 & $5.293 E+05$ & & & \\
\hline
\end{tabular}

Area of basic unit $=6.551 \mathrm{E}-07 \mathrm{~cm}-2$

CHI SQUARED = 7.004144 WITH 25 DEGREES OF FREEDOM

$P($ chi squared $)=96.2 \%$

CORRELATION COEFFICIENT $=0.810$

VARIANCE OF SQR(Ns) $=.4142963$

VARIANCE OF SQR(Ni) $=2.447244$

$\mathrm{Ns} / \mathrm{Ni}=0.159+/-0.017$

MEAN RATIO = $0.176+/-0.018$

Pooled Age $=49.9+/-6.9 \mathrm{Ma}$

Mean Age $=55.2+/-7.3 \mathrm{Ma}$

Central Age $=49.9+/-5.6 \mathrm{Ma}$

$\%$ Variation $=0.02 \%$

Ages calculated using a zeta of $12250+/-1000$ for SRM963a glass

$\mathrm{RHO} D=5.134 \mathrm{E}+04 \mathrm{~cm}-2 ; \mathrm{ND}=2561$ 
94NAC8 Apatite

IRRADIATION WY94-4-6 COUNTED BY: JMM

\begin{tabular}{|c|c|c|c|c|c|c|c|c|c|c|}
\hline No. & Ns & $\mathrm{Ni}$ & $\mathrm{Na}$ & RATIO & $\underset{(p p m)}{U}$ & RHOS & RHOi & $\begin{array}{l}\text { F.T.AGE } \\
\text { (Ma) }\end{array}$ & & \\
\hline 1 & 3 & 29 & 100 & 0.103 & 2.7 & $4.579 \mathrm{E}+04$ & $4.427 \mathrm{E}+05$ & 32.2 & $+/-$ & 19.7 \\
\hline 2 & 3 & 17 & 100 & 0.176 & 1.6 & $4.579 \mathrm{E}+04$ & $2.595 \mathrm{E}+05$ & 54.8 & $+/-$ & 34.6 \\
\hline 3 & 1 & 15 & 60 & 0.067 & 2.3 & $2.544 \mathrm{E}+04$ & $3.816 \mathrm{E}+05$ & 20.7 & $+/-$ & 21.5 \\
\hline 4 & 1 & 80 & 100 & 0.012 & 7.4 & $1.526 \mathrm{E}+04$ & $1.221 \mathrm{E}+06$ & 3.9 & $+/-$ & 3.9 \\
\hline 5 & 1 & 44 & 100 & 0.023 & 4.0 & $1.526 \mathrm{E}+04$ & $6.717 \mathrm{E}+05$ & 7.1 & $+/-$ & 7.2 \\
\hline 6 & 1 & 12 & 80 & 0.083 & 1.4 & $1.908 \mathrm{E}+04$ & $2.290 \mathrm{E}+05$ & 25.9 & $+/-$ & 27.1 \\
\hline 7 & 0 & 18 & 100 & 0.000 & 1.7 & $0.000 \mathrm{E}+00$ & $2.748 \mathrm{E}+05$ & 0.0 & $+1-$ & 0.0 \\
\hline 8 & 1 & 35 & 80 & 0.029 & 4.0 & +04 & $6.678 \mathrm{E}+05$ & 8.9 & $+/-$ & 9.1 \\
\hline 9 & 1 & 38 & 100 & 0.026 & 3.5 & $1.526 \mathrm{E}+04$ & $5.801 \mathrm{E}+05$ & 8.2 & $+/-$ & 8.3 \\
\hline 10 & 1 & 24 & 100 & 0.042 & 2.2 & $1.526 \mathrm{E}+04$ & $3.664 \mathrm{E}+05$ & 13.0 & $+/-$ & 13.3 \\
\hline 11 & 2 & 62 & 70 & 0.032 & 8.1 & $4.361 \mathrm{E}+04$ & $1.352 \mathrm{E}+06$ & 10.0 & $+/-$ & 7.3 \\
\hline 12 & 1 & 22 & 50 & 0.045 & 4.0 & $3.053 \mathrm{E}+04$ & $6.717 \mathrm{E}+05$ & 14.1 & $+/-$ & 14.5 \\
\hline 13 & 1 & 28 & 90 & 0.036 & 2.9 & $1.696 \mathrm{E}+04$ & 4.749E+05 & 11.1 & $+/-$ & 11.4 \\
\hline 14 & 1 & 33 & 100 & 0.030 & 3.0 & $E+04$ & $5.037 \mathrm{E}+05$ & 9.4 & $+/-$ & 9.6 \\
\hline 15 & 2 & 77 & 100 & 0.026 & 7.1 & $3.053 \mathrm{E}+04$ & $1.175 \mathrm{E}+06$ & 8.1 & $+/-$ & 5.8 \\
\hline 16 & 0 & 36 & 100 & 0.000 & 3.3 & $0.000 \mathrm{E}+00$ & $5.495 \mathrm{E}+05$ & 0.0 & $+/-$ & 0.0 \\
\hline 17 & 2 & 24 & 100 & 0.083 & 2.2 & $3.053 \mathrm{E}+04$ & $3.664 \mathrm{E}+05$ & 25.9 & $+/-$ & 19.2 \\
\hline 18 & 0 & 33 & 100 & 0.000 & 3.0 & $0.000 \mathrm{E}+00$ & $5.037 \mathrm{E}+05$ & 0.0 & $+1-$ & 0.0 \\
\hline 19 & 1 & 26 & 80 & 0.038 & 3.0 & $1.908 \mathrm{E}+04$ & $4.961 \mathrm{E}+05$ & 12.0 & $+/-$ & 12.2 \\
\hline 20 & 0 & 37 & 100 & 0.000 & 3.4 & $0.000 \mathrm{E}+00$ & $5.648 \mathrm{E}+05$ & 0.0 & $+1-$ & 0.0 \\
\hline 21 & 1 & 65 & 100 & 0.015 & 6.0 & $1.526 \mathrm{E}+04$ & $9.922 \mathrm{E}+05$ & 4.8 & $+/-$ & 4.8 \\
\hline 22 & 1 & 24 & 80 & 0.042 & 2.8 & $1.908 \mathrm{E}+04$ & $4.579 \mathrm{E}+05$ & 13.0 & $+1-$ & 13.3 \\
\hline 23 & 3 & 34 & 90 & 0.088 & 3.5 & $5.088 \mathrm{E}+04$ & $5.767 \mathrm{E}+05$ & 27.4 & $+/-$ & 16.7 \\
\hline 24 & 0 & 38 & 100 & 0.000 & 3.5 & $0.000 \mathrm{E}+00$ & $5.801 \mathrm{E}+05$ & 0.0 & $+/-$ & 0.0 \\
\hline 25 & 0 & 21 & 90 & & 2.1 & 0.0 & $3.562 \mathrm{E}+05$ & 0.0 & $+/-$ & 0.0 \\
\hline 26 & 1 & 47 & 100 & 0.021 & 4.3 & $1.526 \mathrm{E}+04$ & $7.174 \mathrm{E}+05$ & 6.6 & $+1-$ & 6.7 \\
\hline 27 & 1 & 29 & 100 & 0.034 & 2.7 & $1.526 \mathrm{E}+04$ & $4.427 \mathrm{E}+05$ & 10.7 & $+1-$ & 11.0 \\
\hline 28 & 0 & 22 & 80 & 0.000 & 2.5 & $0.000 \mathrm{E}+00$ & $4.198 \mathrm{E}+05$ & 0.0 & $+/-$ & 0.0 \\
\hline 29 & 0 & 19 & 30 & 0.000 & 5.8 & $0.000 \mathrm{E}+00$ & $9.668 \mathrm{E}+05$ & 0.0 & $+/-$ & 0.0 \\
\hline 30 & 0 & 29 & 100 & 0.000 & 2.7 & $0.000 \mathrm{E}+00$ & $4.427 \mathrm{E}+05$ & 0.0 & $+/-$ & 0.0 \\
\hline \multirow[t]{2}{*}{31} & 0 & 30 & 50 & 0.000 & 5.5 & $0.000 \mathrm{E}+00$ & $9.159 \mathrm{E}+05$ & 0.0 & $+1-$ & 0.0 \\
\hline & 30 & 1048 & & & 3.5 & 1.677E+04 & $5.860 \mathrm{E}+05$ & & & \\
\hline
\end{tabular}

Area of basic unit $=6.551 \mathrm{E}-07 \mathrm{~cm}-2$

CHI SQUARED = 17.14536 WITH 30 DEGREES OF FREEDOM

$\mathrm{P}($ chi squared $)=7.8 \%$

CORRELATION COEFFICIENT $=0.159$

VARIANCE OF SQR(Ns) $=.3577907$

VARIANCE OF SQR(Ni) $=1.800645$

$\mathrm{Ns} / \mathrm{Ni}=0.029+/-0.005$

MEAN RATIO $=0.034+/-0.007$

Pooled Age $=8.9+/-1.8 \mathrm{Ma}$

Mean Age $=10.6+/-2.4 \mathrm{Ma}$

Central Age $=8.9+/-1.7 \mathrm{Ma}$

$\%$ Variation $=10.48 \%$

Ages calculated using a zeta of $12250+/$ - 1000 for SRM963a glass

$\mathrm{RHO} D=5.087 \mathrm{E}+04 \mathrm{~cm}-2 ; \mathrm{ND}=2561$ 
N Aleutian COST \#1 well Zircon FT data summary

\begin{tabular}{|c|c|c|c|c|c|c|c|c|c|c|c|c|}
\hline 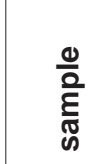 & 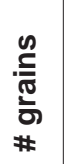 & n & $\bar{z}$ & 㐘 & 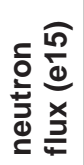 & 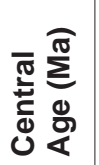 & 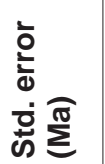 & 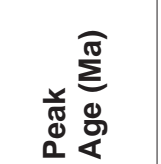 & 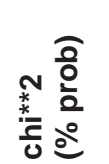 & $\supset$ & 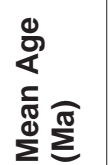 & 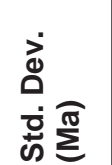 \\
\hline $\mathrm{AC1}$ & 20 & 2661 & 2152 & & 1.78 & 68.6 & 9.9 & $\begin{array}{r}82,12,23 \\
36,47\end{array}$ & $<1$ & 580 & 82 & 44 \\
\hline NAC2 & 30 & 3858 & 3554 & 4 & 1.77 & 57.5 & 5.2 & $48,28,83$ & $<1$ & 535 & 59 & 32 \\
\hline NAC3 & 29 & 1960 & 2065 & 5.20 & 1.76 & 50.2 & 5.5 & 25,82 & $<1$ & 437 & 64 & 35 \\
\hline NAC5 & 40 & 4981 & 5363 & & 1.74 & 46.9 & & $27,50,85$ & $<$ & 57 & 53 & 30 \\
\hline NAC6 & 20 & 827 & 1161 & $2.50 \mathrm{E}-04$ & 1.73 & 36.7 & 2.5 & 35 & $<1$ & 508 & 38 & 10 \\
\hline NAC8 & 14 & 591 & 757 & $2.10 \mathrm{E}-04$ & 1.71 & 39.2 & 4.2 & 32 & $<1$ & 406 & 41 & 14 \\
\hline
\end{tabular}

Individual Zircon Grain Data

\begin{tabular}{|c|c|c|c|c|c|c|c|c|c|c|}
\hline Sample & Flux & Grain \# & color & shape & $\begin{array}{c}\text { Area } \\
\left(\mathrm{cm}^{* * 2}\right)\end{array}$ & Ns & $\mathrm{Ni}$ & U (ppm) & $\begin{array}{l}\text { FT Age } \\
\text { (Ma) }\end{array}$ & $\begin{array}{l}\text { Std.Error } \\
\text { (Ma) }\end{array}$ \\
\hline 94NAC1 & $1.78 \mathrm{E}+15$ & 1 & B & $\mathrm{SH}$ & 8.00E-06 & 65 & 39 & 526 & 88.1 & 18.1 \\
\hline 94NAC1 & $1.78 \mathrm{E}+15$ & 2 & YB & $\mathrm{SH}$ & 1.20E-05 & 162 & 69 & 620 & 123.8 & 18.3 \\
\hline 94NAC1 & $1.78 \mathrm{E}+15$ & 3 & $B$ & SR & $2.00 \mathrm{E}-05$ & 153 & 70 & 378 & 115.4 & 17.1 \\
\hline 94NAC1 & $1.78 \mathrm{E}+15$ & 4 & $\mathrm{Y}$ & $E$ & 4.00E-05 & 160 & 89 & 240 & 95.0 & 13.0 \\
\hline 94NAC1 & $1.78 \mathrm{E}+15$ & 5 & $\mathrm{Y}$ & $\mathrm{SH}$ & 4.00E-05 & 77 & 78 & 210 & 52.4 & 8.6 \\
\hline 94NAC1 & $1.78 \mathrm{E}+15$ & 6 & YB & $\mathrm{SH}$ & $2.00 \mathrm{E}-05$ & 127 & 89 & 480 & 75.5 & 10.8 \\
\hline 94NAC1 & $1.78 \mathrm{E}+15$ & 7 & $B$ & $\mathrm{SH}$ & $2.00 \mathrm{E}-05$ & 165 & 114 & 615 & 76.6 & 9.7 \\
\hline 94NAC1 & $1.78 \mathrm{E}+15$ & 8 & $B$ & $E$ & 2.00E-05 & 110 & 258 & 1391 & 22.7 & 2.7 \\
\hline 94NAC1 & $1.78 \mathrm{E}+15$ & 9 & $\mathrm{Y}$ & $\mathrm{SH}$ & $2.00 \mathrm{E}-05$ & 100 & 61 & 329 & 86.7 & 14.4 \\
\hline 94NAC1 & $1.78 \mathrm{E}+15$ & 10 & $\mathrm{Y}$ & $E$ & $2.00 \mathrm{E}-05$ & 65 & 121 & 653 & 28.5 & 4.5 \\
\hline 94NAC1 & $1.78 \mathrm{E}+15$ & 11 & $\mathrm{O}$ & $E$ & 4.00E-05 & 167 & 193 & 520 & 45.9 & 5.1 \\
\hline 94NAC1 & $1.78 \mathrm{E}+15$ & 12 & B & SR & 3.20E-05 & 171 & 251 & 846 & 36.2 & 3.8 \\
\hline 94NAC1 & $1.78 \mathrm{E}+15$ & 13 & $\mathrm{Y}$ & $\mathrm{SH}$ & 4.00E-05 & 265 & 210 & 566 & 66.8 & 6.6 \\
\hline 94NAC1 & $1.78 \mathrm{E}+15$ & 14 & $\mathrm{O}$ & SR & 2.00E-05 & 221 & 64 & 345 & 181.3 & 26.5 \\
\hline 94NAC1 & $1.78 \mathrm{E}+15$ & 15 & YB & $\mathrm{SH}$ & $2.00 \mathrm{E}-05$ & 176 & 60 & 324 & 154.3 & 23.7 \\
\hline 94NAC1 & $1.78 \mathrm{E}+15$ & 16 & 0 & $\mathrm{SH}$ & $1.20 \mathrm{E}-05$ & 86 & 50 & 449 & 90.9 & 16.5 \\
\hline 94NAC1 & $1.78 \mathrm{E}+15$ & 17 & $\mathrm{Y}$ & $\mathrm{SH}$ & 1.20E-05 & 71 & 30 & 270 & 124.8 & 27.5 \\
\hline 94NAC1 & $1.78 \mathrm{E}+15$ & 18 & $B$ & $E$ & 7.20E-06 & 27 & 124 & 1858 & 11.6 & 2.5 \\
\hline 94NAC1 & $1.78 \mathrm{E}+15$ & 19 & $B$ & SR & $2.00 \mathrm{E}-05$ & 113 & 74 & 399 & 80.8 & 12.4 \\
\hline 94NAC1 & $1.78 \mathrm{E}+15$ & 20 & $\mathrm{Y}$ & $E$ & $2.00 \mathrm{E}-05$ & 180 & 108 & 582 & 88.1 & 11.1 \\
\hline NAC2 & $1.77 \mathrm{E}+15$ & 1 & B & $\mathrm{SH}$ & 1.60E-05 & 153 & 97 & 658 & 83.0 & 11.1 \\
\hline NAC2 & $1.77 \mathrm{E}+15$ & 2 & $B$ & $\mathrm{SH}$ & 1.20E-05 & 82 & 90 & 814 & 48.1 & 7.5 \\
\hline NAC2 & $1.77 \mathrm{E}+15$ & 3 & YB & $\mathrm{SH}$ & $1.20 \mathrm{E}-05$ & 100 & 92 & 832 & 57.3 & 8.5 \\
\hline NAC2 & $1.77 \mathrm{E}+15$ & 4 & $B$ & $E$ & $2.00 \mathrm{E}-05$ & 57 & 52 & 282 & 57.8 & 11.3 \\
\hline NAC2 & $1.77 \mathrm{E}+15$ & 5 & $\mathrm{Y}$ & $E$ & 3.20E-05 & 84 & 84 & 285 & 52.7 & 8.3 \\
\hline NAC2 & $1.77 \mathrm{E}+15$ & 6 & $\mathrm{Y}$ & $\mathrm{SH}$ & $2.00 \mathrm{E}-05$ & 303 & 195 & 1058 & 81.8 & 8.0 \\
\hline NAC2 & $1.77 \mathrm{E}+15$ & 7 & $\mathrm{Y}$ & $\mathrm{SH}$ & $2.00 \mathrm{E}-05$ & 162 & 188 & 1020 & 45.5 & 5.1 \\
\hline NAC2 & $1.77 \mathrm{E}+15$ & 8 & YB & $\mathrm{SH}$ & 2.00E-05 & 231 & 95 & 515 & 127.5 & 16.1 \\
\hline NAC2 & $1.77 \mathrm{E}+15$ & 9 & YB & $E$ & 2.00E-05 & 180 & 190 & 1031 & 50.0 & 5.5 \\
\hline NAC2 & $1.77 \mathrm{E}+15$ & 10 & $\mathrm{Y}$ & $\mathrm{SH}$ & 4.00E-05 & 200 & 112 & 304 & 93.9 & 11.5 \\
\hline NAC2 & $1.77 \mathrm{E}+15$ & 11 & $\mathrm{Y}$ & $E$ & 8.00E-06 & 63 & 69 & 936 & 48.2 & 8.6 \\
\hline NAC2 & $1.77 \mathrm{E}+15$ & 12 & YB & $E$ & 2.00E-05 & 202 & 111 & 602 & 95.6 & 11.8 \\
\hline NAC2 & $1.77 \mathrm{E}+15$ & 13 & $\mathrm{Y}$ & $\mathrm{SH}$ & 2.00E-05 & 112 & 50 & 271 & 117.5 & 20.4 \\
\hline NAC2 & $1.77 \mathrm{E}+15$ & 14 & RB & $\mathrm{SH}$ & 2.00E-05 & 58 & 51 & 277 & 59.9 & 11.7 \\
\hline
\end{tabular}




\begin{tabular}{|c|c|c|c|c|c|c|c|c|c|c|}
\hline Sample & Flux & Grain \# & color & shape & $\begin{array}{c}\text { Area } \\
\left(\mathrm{cm}^{\star *} 2\right)\end{array}$ & Ns & $\mathrm{Ni}$ & U (ppm) & $\begin{array}{l}\text { FT Age } \\
\text { (Ma) }\end{array}$ & $\begin{array}{l}\text { Std.Error } \\
\text { (Ma) }\end{array}$ \\
\hline NAC2 & $1.77 \mathrm{E}+15$ & 15 & $\mathrm{Y}$ & SR & 1.60E-05 & 50 & 69 & 468 & 38.3 & 7.2 \\
\hline NAC2 & $1.77 \mathrm{E}+15$ & 16 & $\mathrm{Y}$ & $\mathrm{SH}$ & 1.20E-05 & 36 & 39 & 353 & 48.7 & 11.4 \\
\hline NAC2 & $1.77 \mathrm{E}+15$ & 17 & $\mathrm{O}$ & $\mathrm{SH}$ & $2.00 \mathrm{E}-05$ & 87 & 164 & 889 & 28.0 & 3.8 \\
\hline NAC2 & $1.77 \mathrm{E}+15$ & 18 & $\bar{Y}$ & SR & $2.00 \mathrm{E}-05$ & 164 & 345 & 1871 & 25.1 & 2.5 \\
\hline NAC2 & $1.77 \mathrm{E}+15$ & 19 & $\mathrm{Y}$ & $\mathrm{SH}$ & 2.00E-05 & 105 & 99 & 537 & 55.9 & 8.1 \\
\hline NAC2 & $1.77 \mathrm{E}+15$ & 20 & $B$ & $\mathrm{SH}$ & 4.00E-05 & 130 & 240 & 651 & 28.6 & 3.3 \\
\hline NAC2 & $1.77 \mathrm{E}+15$ & 21 & RB & $E$ & 4.00E-05 & 226 & 105 & 285 & 113.0 & 13.9 \\
\hline NAC2 & $1.77 \mathrm{E}+15$ & 22 & $B$ & $\mathrm{SH}$ & 2.00E-05 & 127 & 178 & 965 & 37.7 & 4.6 \\
\hline NAC2 & $1.77 \mathrm{E}+15$ & 23 & YB & $E$ & 8.00E-05 & 70 & 62 & 84 & 59.5 & 10.6 \\
\hline NAC2 & $1.77 \mathrm{E}+15$ & 24 & $\bar{Y}$ & $E$ & $2.00 \mathrm{E}-05$ & 61 & 78 & 423 & 41.3 & 7.2 \\
\hline NAC2 & $1.77 \mathrm{E}+15$ & 25 & & $\mathrm{E}$ & 4.00E-05 & 97 & 129 & 350 & 39.7 & 5.5 \\
\hline NAC2 & $1.77 \mathrm{E}+15$ & 26 & $\bar{Y}$ & $\mathrm{SH}$ & $2.00 \mathrm{E}-05$ & 113 & 119 & 645 & 50.1 & 6.8 \\
\hline NAC2 & $1.77 \mathrm{E}+15$ & 27 & $B$ & $\mathrm{SH}$ & $2.00 \mathrm{E}-05$ & 221 & 114 & 618 & 101.8 & 12.2 \\
\hline NAC2 & $1.77 \mathrm{E}+15$ & 28 & YB & $E$ & $2.00 \mathrm{E}-05$ & 173 & 121 & 656 & 75.3 & 9.3 \\
\hline NAC2 & $1.77 \mathrm{E}+15$ & 29 & $\bar{Y}$ & $E$ & 4.00E-05 & 100 & 175 & 475 & 30.2 & 3.9 \\
\hline NAC2 & $1.77 \mathrm{E}+15$ & 30 & $B$ & $E$ & 1.20E-05 & 111 & 41 & 371 & 141.8 & 26.4 \\
\hline NAC3 & $1.76 \mathrm{E}+15$ & 1 & $\bar{Y}$ & $\mathrm{SH}$ & $2.40 \mathrm{E}-05$ & 85 & 193 & 877 & 23.1 & 3.1 \\
\hline NAC3 & $1.76 \mathrm{E}+15$ & 2 & $\mathrm{Y}$ & $\mathrm{SH}$ & $1.20 \mathrm{E}-05$ & 19 & 29 & 264 & 34.4 & 10.2 \\
\hline NAC3 & $1.76 \mathrm{E}+15$ & 3 & $\mathrm{Y}$ & $\mathrm{E}$ & 2.00E-05 & 126 & 78 & 425 & 84.5 & 12.5 \\
\hline NAC3 & $1.76 \mathrm{E}+15$ & 4 & $\mathrm{Y}$ & $\mathrm{SH}$ & 1.20E-05 & 86 & 92 & 836 & 49.0 & 7.5 \\
\hline NAC3 & $1.76 \mathrm{E}+15$ & 5 & YB & $\mathrm{SH}$ & 2.00E-05 & 160 & 94 & 513 & 89.0 & 12.0 \\
\hline NAC3 & $1.76 \mathrm{E}+15$ & 6 & $\mathrm{O}$ & $E$ & 2.00E-05 & 56 & 121 & 660 & 24.3 & 4.0 \\
\hline NAC3 & $1.76 \mathrm{E}+15$ & 7 & B & $\mathrm{SH}$ & 1.20E-05 & 67 & 37 & 336 & 94.6 & 19.7 \\
\hline NAC3 & $1.76 \mathrm{E}+15$ & 8 & $\bar{Y}$ & $E$ & 1.20E-05 & 21 & 27 & 245 & 40.8 & 12.0 \\
\hline NAC3 & $1.76 \mathrm{E}+15$ & 9 & $\bar{Y}$ & $\mathrm{SH}$ & $1.28 \mathrm{E}-05$ & 50 & 80 & 682 & 32.8 & 6.0 \\
\hline NAC3 & $1.76 \mathrm{E}+15$ & 10 & $\mathrm{O}$ & $E$ & 8.00E-06 & 66 & 49 & 668 & 70.5 & 13.5 \\
\hline NAC3 & $1.76 \mathrm{E}+15$ & 11 & $\mathrm{O}$ & $E$ & 1.20E-05 & 40 & 15 & 136 & 138.9 & 42.3 \\
\hline NAC3 & $1.76 \mathrm{E}+15$ & 12 & $\mathrm{Y}$ & $\mathrm{SH}$ & 1.20E-05 & 81 & 40 & 364 & 105.7 & 20.8 \\
\hline NAC3 & $1.76 \mathrm{E}+15$ & 13 & YB & SR & 1.20E-05 & 64 & 50 & 455 & 67.0 & 12.9 \\
\hline NAC3 & $1.76 \mathrm{E}+15$ & 14 & $\mathrm{O}$ & $\mathrm{SH}$ & $2.40 \mathrm{E}-05$ & 21 & 46 & 209 & 24.0 & 6.4 \\
\hline NAC3 & $1.76 \mathrm{E}+15$ & 15 & $\mathrm{O}$ & $E$ & 2.00E-05 & 92 & 58 & 316 & 83.0 & 14.2 \\
\hline NAC3 & $1.76 \mathrm{E}+15$ & 16 & $\mathrm{O}$ & $\mathrm{SH}$ & $1.28 \mathrm{E}-05$ & 56 & 50 & 426 & 58.7 & 11.6 \\
\hline NAC3 & $1.76 \mathrm{E}+15$ & 17 & $\mathrm{O}$ & $\mathrm{SH}$ & 1.20E-05 & 41 & 59 & 536 & 36.5 & 7.5 \\
\hline NAC3 & $1.76 \mathrm{E}+15$ & 18 & $\mathrm{O}$ & $\mathrm{SH}$ & 4.00E-05 & 135 & 211 & 575 & 33.6 & 3.9 \\
\hline NAC3 & $1.76 \mathrm{E}+15$ & 19 & $Y$ & $E$ & 2.00E-05 & 68 & 32 & 175 & 110.9 & 24.1 \\
\hline NAC3 & $1.76 \mathrm{E}+15$ & 20 & $\mathrm{O}$ & $\mathrm{SH}$ & 4.00E-05 & 58 & 118 & 322 & 25.8 & 4.2 \\
\hline NAC3 & $1.76 \mathrm{E}+15$ & 21 & YB & $\mathrm{SH}$ & 2.00E-05 & 123 & 83 & 453 & 77.6 & 11.3 \\
\hline NAC3 & $1.76 \mathrm{E}+15$ & 22 & $B$ & $E$ & 1.28E-05 & 44 & 67 & 571 & 34.5 & 6.8 \\
\hline NAC3 & $1.76 \mathrm{E}+15$ & 23 & $\bar{Y}$ & $\mathrm{SH}$ & 1.20E-05 & 30 & 51 & 464 & 30.9 & 7.2 \\
\hline NAC3 & $1.76 \mathrm{E}+15$ & 24 & YB & $E$ & $1.28 \mathrm{E}-05$ & 90 & 36 & 307 & 130.3 & 26.1 \\
\hline NAC3 & $1.76 \mathrm{E}+15$ & 25 & YB & $E$ & 1.60E-05 & 39 & 95 & 648 & 21.6 & 4.2 \\
\hline NAC3 & $1.76 \mathrm{E}+15$ & 26 & YB & $E$ & $2.00 \mathrm{E}-05$ & 26 & 47 & 256 & 29.1 & 7.2 \\
\hline NAC3 & $1.76 \mathrm{E}+15$ & 27 & YB & $\mathrm{SH}$ & 4.00E-05 & 129 & 75 & 205 & 89.9 & 13.4 \\
\hline NAC3 & $1.76 \mathrm{E}+15$ & 28 & $B$ & SR & 1.20E-05 & 50 & 56 & 509 & 46.8 & 9.3 \\
\hline NAC3 & $1.76 \mathrm{E}+15$ & 29 & $\bar{Y}$ & $\mathrm{SH}$ & 1.20E-05 & 37 & 76 & 691 & 25.6 & 5.2 \\
\hline NAC5 & $1.74 \mathrm{E}+15$ & 1 & $E$ & $B$ & 2.00E-05 & 60 & 110 & 607 & 28.3 & 4.6 \\
\hline NAC5 & $1.74 \mathrm{E}+15$ & 2 & YB & $E$ & 2.00E-05 & 125 & 93 & 513 & 69.6 & 9.8 \\
\hline NAC5 & $1.74 \mathrm{E}+15$ & 3 & B & $\mathrm{SH}$ & $4.00 \mathrm{E}-05$ & 440 & 173 & 477 & 131.0 & 12.6 \\
\hline NAC5 & $1.74 \mathrm{E}+15$ & 4 & YB & $\mathrm{SH}$ & 1.20E-05 & 72 & 46 & 423 & 81.0 & 15.5 \\
\hline NAC5 & $1.74 \mathrm{E}+15$ & 5 & B & $\mathrm{SH}$ & 1.60E-05 & 68 & 70 & 483 & 50.4 & 8.7 \\
\hline NAC5 & $1.74 \mathrm{E}+15$ & 6 & YB & $\mathrm{SH}$ & 2.00E-05 & 87 & 98 & 541 & 46.0 & 7.0 \\
\hline NAC5 & $1.74 \mathrm{E}+15$ & 7 & YB & $\mathrm{SH}$ & 4.00E-05 & 197 & 271 & 748 & 37.7 & 3.8 \\
\hline NAC5 & $1.74 \mathrm{E}+15$ & 8 & YB & $\mathrm{SH}$ & 4.00E-05 & 120 & 247 & 681 & 25.2 & 2.9 \\
\hline
\end{tabular}




\begin{tabular}{|c|c|c|c|c|c|c|c|c|c|c|}
\hline Sample & Flux & Grain \# & color & shape & $\begin{array}{c}\text { Area } \\
\left(\mathrm{cm}^{\star *} 2\right)\end{array}$ & Ns & $\mathrm{Ni}$ & $\mathrm{U}(\mathrm{ppm})$ & $\begin{array}{c}\text { FT Age } \\
(\mathrm{Ma})\end{array}$ & $\begin{array}{c}\text { Std.Error } \\
\text { (Ma) }\end{array}$ \\
\hline NAC5 & $1.74 \mathrm{E}+15$ & 9 & B & $\mathrm{SH}$ & $2.00 \mathrm{E}-05$ & 87 & 165 & 910 & 27.4 & 3.7 \\
\hline NAC5 & $1.74 \mathrm{E}+15$ & 10 & $\mathrm{Y}$ & $\mathrm{SH}$ & 2.00E-05 & 66 & 105 & 579 & 32.6 & 5.2 \\
\hline NAC5 & $1.74 \mathrm{E}+15$ & 11 & $\mathrm{Y}$ & $\mathrm{E}$ & 2.00E-05 & 86 & 135 & 745 & 33.1 & 4.7 \\
\hline NAC5 & $1.74 \mathrm{E}+15$ & 12 & YB & $E$ & 1.20E-05 & 40 & 72 & 662 & 28.9 & 5.8 \\
\hline NAC5 & $1.74 \mathrm{E}+15$ & 13 & B & $\mathrm{SH}$ & 1.20E-05 & 43 & 90 & 828 & 24.8 & 4.7 \\
\hline NAC5 & $1.74 \mathrm{E}+15$ & 14 & YB & $\mathrm{SH}$ & $2.00 \mathrm{E}-05$ & 89 & 54 & 298 & 85.2 & 15.0 \\
\hline NAC5 & $1.74 \mathrm{E}+15$ & 15 & $\mathrm{Y}$ & $\mathrm{SH}$ & $2.00 \mathrm{E}-05$ & 89 & 200 & 1103 & 23.1 & 3.1 \\
\hline NAC5 & $1.74 \mathrm{E}+15$ & 16 & $B$ & $\mathrm{SH}$ & 4.00E-05 & 150 & 207 & 571 & 37.6 & 4.2 \\
\hline NAC5 & $1.74 \mathrm{E}+15$ & 17 & $\mathrm{O}$ & $\mathrm{SH}$ & $2.00 \mathrm{E}-05$ & 130 & 137 & 756 & 49.2 & 6.3 \\
\hline NAC5 & $1.74 \mathrm{E}+15$ & 18 & B & $\mathrm{SH}$ & 8.00E-05 & 186 & 352 & 486 & 27.4 & 2.7 \\
\hline NAC5 & $1.74 \mathrm{E}+15$ & 19 & $B$ & $\mathrm{SH}$ & 4.00E-05 & 233 & 252 & 695 & 48.0 & 4.7 \\
\hline NAC5 & $1.74 \mathrm{E}+15$ & 20 & $\mathrm{Y}$ & $\mathrm{SH}$ & 4.00E-05 & 117 & 207 & 571 & 29.4 & 3.5 \\
\hline NAC5 & $1.74 \mathrm{E}+15$ & 21 & YB & $\mathrm{SH}$ & $2.00 \mathrm{E}-05$ & 102 & 86 & 474 & 61.4 & 9.2 \\
\hline NAC5 & $1.74 \mathrm{E}+15$ & 22 & $\mathrm{O}$ & $\mathrm{SH}$ & 4.00E-05 & 247 & 235 & 648 & 54.5 & 5.3 \\
\hline NAC5 & $1.74 \mathrm{E}+15$ & 23 & $B$ & $E$ & 2.00E-05 & 134 & 83 & 458 & 83.5 & 12.0 \\
\hline NAC5 & $1.74 \mathrm{E}+15$ & 24 & $\mathrm{Y}$ & $\mathrm{SH}$ & 8.00E-06 & 39 & 20 & 276 & 100.7 & 27.9 \\
\hline NAC5 & $1.74 \mathrm{E}+15$ & 25 & $\mathrm{Y}$ & $\mathrm{SH}$ & 1.20E-05 & 34 & 38 & 349 & 46.4 & 11.1 \\
\hline NAC5 & $1.74 \mathrm{E}+15$ & 26 & $B$ & $\mathrm{SH}$ & 4.00E-05 & 263 & 250 & 690 & 54.5 & 5.2 \\
\hline NAC5 & $1.74 \mathrm{E}+15$ & 27 & $\mathrm{Y}$ & $\mathrm{SH}$ & 2.00E-05 & 43 & 90 & 497 & 24.8 & 4.7 \\
\hline NAC5 & $1.74 \mathrm{E}+15$ & 28 & YB & $\mathrm{R}$ & 4.00E-05 & 209 & 127 & 350 & 85.1 & 10.0 \\
\hline NAC5 & $1.74 \mathrm{E}+15$ & 29 & YB & $\mathrm{SH}$ & 2.00E-05 & 206 & \begin{tabular}{|l|}
94 \\
\end{tabular} & 519 & 113.1 & 14.6 \\
\hline NAC5 & $1.74 \mathrm{E}+15$ & 30 & $\mathrm{~B}$ & $E$ & $1.20 \mathrm{E}-05$ & 39 & 57 & 524 & 35.5 & 7.5 \\
\hline NAC5 & $1.74 \mathrm{E}+15$ & 31 & $\mathrm{Y}$ & $\bar{E}$ & $2.00 \mathrm{E}-05$ & 43 & 106 & 585 & 21.1 & 3.9 \\
\hline NAC5 & $1.74 \mathrm{E}+15$ & 32 & YB & $\mathrm{SH}$ & 2.00E-05 & 81 & 85 & 469 & 49.4 & 7.9 \\
\hline NAC5 & $1.74 \mathrm{E}+15$ & 33 & $\mathrm{Y}$ & $\mathrm{SH}$ & $2.00 \mathrm{E}-05$ & 109 & 90 & 497 & 62.7 & 9.2 \\
\hline NAC5 & $1.74 \mathrm{E}+15$ & 34 & $B$ & $\mathrm{SH}$ & 4.00E-05 & 157 & 196 & 541 & 41.6 & 4.7 \\
\hline NAC5 & $1.74 \mathrm{E}+15$ & 35 & YB & $\mathrm{SH}$ & $2.00 \mathrm{E}-05$ & 73 & 132 & 728 & 28.7 & 4.3 \\
\hline NAC5 & $1.74 \mathrm{E}+15$ & 36 & YB & $\mathrm{SH}$ & $2.00 \mathrm{E}-05$ & 50 & \begin{tabular}{|l|}
92 \\
\end{tabular} & 508 & 28.2 & 5.1 \\
\hline NAC5 & $1.74 \mathrm{E}+15$ & 37 & YB & $E$ & 4.00E-05 & 256 & 225 & 621 & 59.0 & 5.8 \\
\hline NAC5 & $1.74 \mathrm{E}+15$ & 38 & YB & SR & 2.00E-05 & 133 & 55 & 303 & 124.7 & 20.4 \\
\hline NAC5 & $1.74 \mathrm{E}+15$ & 39 & $\mathrm{Y}$ & $E$ & 2.00E-05 & 160 & 81 & 447 & 102.0 & 14.3 \\
\hline NAC5 & $1.74 \mathrm{E}+15$ & 40 & $\mathrm{Y}$ & $\mathrm{SH}$ & $2.00 \mathrm{E}-05$ & 118 & 137 & 756 & 44.7 & 5.8 \\
\hline NAC6 & $1.73 \mathrm{E}+15$ & 1 & B & $\mathrm{SH}$ & 8.00E-06 & 16 & 30 & 416 & 27.5 & 8.6 \\
\hline NAC6 & $1.73 \mathrm{E}+15$ & 2 & $B$ & $E$ & $2.40 \mathrm{E}-05$ & 63 & 100 & 462 & 32.5 & 5.3 \\
\hline NAC6 & $1.73 \mathrm{E}+15$ & 3 & B & SR & -05 & 60 & 95 & 879 & 32.6 & 5.5 \\
\hline NAC6 & $1.73 \mathrm{E}+15$ & 4 & YB & $E$ & 1.60E-05 & 45 & 74 & 513 & 31.4 & 6.0 \\
\hline NAC6 & $1.73 \mathrm{E}+15$ & 5 & YB & $\mathrm{SH}$ & 6.00E-06 & 23 & 34 & 629 & 34.9 & 9.5 \\
\hline NAC6 & $1.73 \mathrm{E}+15$ & 6 & YB & $\mathrm{SH}$ & 1.60E-05 & 31 & 38 & 264 & 42.1 & 10.3 \\
\hline NAC6 & $1.73 \mathrm{E}+15$ & 7 & YB & SR & 1.20E-05 & 14 & 25 & 231 & 28.9 & 9.7 \\
\hline NAC6 & $1.73 \mathrm{E}+15$ & 8 & B & SR & 1.28E-05 & 46 & 68 & 590 & 34.9 & 6.8 \\
\hline NAC6 & $1.73 \mathrm{E}+15$ & 9 & $B$ & $\mathrm{SH}$ & 1.20E-05 & 34 & 41 & 379 & 42.8 & 10.0 \\
\hline NAC6 & $1.73 \mathrm{E}+15$ & 10 & YB & SR & 1.60E-05 & 84 & 88 & 610 & 49.2 & 7.7 \\
\hline NAC6 & $1.73 \mathrm{E}+15$ & 11 & YB & $\mathrm{SH}$ & 2.00E-05 & 23 & 65 & 361 & 18.3 & 4.5 \\
\hline NAC6 & $1.73 \mathrm{E}+15$ & 12 & YB & $\mathrm{SH}$ & 9.60E-06 & 46 & 68 & 786 & 34.9 & 6.8 \\
\hline NAC6 & $1.73 \mathrm{E}+15$ & 13 & YB & $\mathrm{SH}$ & 6.00E-06 & 26 & 35 & 647 & 38.3 & 10.0 \\
\hline NAC6 & $1.73 \mathrm{E}+15$ & 14 & YB & $\mathrm{SH}$ & 9.60E-06 & 16 & 33 & 382 & 25.0 & 7.7 \\
\hline NAC6 & $1.73 \mathrm{E}+15$ & 15 & $\mathrm{O}$ & $\mathrm{E}$ & 9.60E-06 & 44 & 60 & 694 & 37.8 & 7.6 \\
\hline NAC6 & $1.73 \mathrm{E}+15$ & 16 & $B$ & $\mathrm{SH}$ & 8.00E-06 & 40 & 40 & 555 & 51.5 & 11.7 \\
\hline NAC6 & $1.73 \mathrm{E}+15$ & 17 & $Y$ & $\mathrm{SH}$ & 8.00E-06 & 21 & 19 & 264 & 56.9 & 18.1 \\
\hline NAC6 & $1.73 \mathrm{E}+15$ & 18 & $\mathrm{Y}$ & $E$ & $2.00 \mathrm{E}-05$ & 74 & 100 & 555 & 38.2 & 6.0 \\
\hline NAC6 & $1.73 \mathrm{E}+15$ & 19 & $B$ & $\mathrm{R}$ & $2.00 \mathrm{E}-05$ & 86 & 117 & 649 & 37.9 & 5.5 \\
\hline NAC6 & $1.73 \mathrm{E}+15$ & 20 & B & SR & 8.00E-06 & 35 & 31 & 430 & 58.2 & 14.5 \\
\hline NAC8 & $1.71 \mathrm{E}+15$ & 1 & $B$ & $\mathrm{SH}$ & 1.20E-05 & 30 & 85 & 795 & 18.0 & 3.9 \\
\hline
\end{tabular}




\begin{tabular}{|l|c|c|c|c|c|c|c|c|c|c|}
\hline Sample & Flux & Grain \# & color & shape & $\begin{array}{c}\text { Area } \\
\left(\mathbf{c m}^{* *} \mathbf{2}\right)\end{array}$ & $\mathbf{N s}$ & $\mathbf{N i}$ & $\mathbf{U}(\mathbf{p p m})$ & $\begin{array}{c}\text { FT Age } \\
\mathbf{( M a )}\end{array}$ & $\begin{array}{c}\text { Std.Error } \\
\mathbf{( M a})\end{array}$ \\
\hline NAC8 & $1.71 \mathrm{E}+15$ & 2 & $\mathrm{YB}$ & $\mathrm{SH}$ & $1.60 \mathrm{E}-05$ & 109 & 130 & 912 & 42.8 & 5.7 \\
\hline NAC8 & $1.71 \mathrm{E}+15$ & 3 & $\mathrm{Y}$ & $\mathrm{SH}$ & $1.20 \mathrm{E}-05$ & 19 & 43 & 402 & 22.6 & 6.3 \\
\hline NAC8 & $1.71 \mathrm{E}+15$ & 4 & $\mathrm{Y}$ & $\mathrm{E}$ & $2.40 \mathrm{E}-05$ & 75 & 66 & 309 & 57.9 & 10.0 \\
\hline NAC8 & $1.71 \mathrm{E}+15$ & 5 & $\mathrm{Y}$ & $\mathrm{SH}$ & $7.20 \mathrm{E}-06$ & 21 & 26 & 405 & 41.2 & 12.2 \\
\hline NAC8 & $1.71 \mathrm{E}+15$ & 6 & $\mathrm{Y}$ & $\mathrm{SH}$ & $1.60 \mathrm{E}-05$ & 63 & 54 & 379 & 59.4 & 11.2 \\
\hline NAC8 & $1.71 \mathrm{E}+15$ & 7 & $\mathrm{YB}$ & $\mathrm{E}$ & $2.00 \mathrm{E}-05$ & 41 & 40 & 225 & 52.2 & 11.7 \\
\hline NAC8 & $1.71 \mathrm{E}+15$ & 8 & $\mathrm{~B}$ & $\mathrm{SR}$ & $2.00 \mathrm{E}-05$ & 52 & 85 & 477 & 31.2 & 5.6 \\
\hline NAC8 & $1.71 \mathrm{E}+15$ & 9 & $\mathrm{YB}$ & $\mathrm{E}$ & $7.20 \mathrm{E}-06$ & 31 & 26 & 405 & 60.7 & 16.3 \\
\hline NAC8 & $1.71 \mathrm{E}+15$ & 10 & $\mathrm{YB}$ & $\mathrm{SH}$ & $1.20 \mathrm{E}-05$ & 48 & 48 & 449 & 51.0 & 10.5 \\
\hline NAC8 & $1.71 \mathrm{E}+15$ & 11 & $\mathrm{O}$ & $\mathrm{SH}$ & $2.00 \mathrm{E}-05$ & 14 & 26 & 146 & 27.5 & 9.2 \\
\hline NAC8 & $1.71 \mathrm{E}+15$ & 12 & $\mathrm{Y}$ & $\mathrm{SH}$ & $1.60 \mathrm{E}-05$ & 28 & 51 & 358 & 28.0 & 6.7 \\
\hline NAC8 & $1.71 \mathrm{E}+15$ & 13 & $\mathrm{~B}$ & $\mathrm{E}$ & $2.00 \mathrm{E}-05$ & 33 & 47 & 264 & 35.8 & 8.2 \\
\hline NAC8 & $1.71 \mathrm{E}+15$ & 14 & $\mathrm{O}$ & $\mathrm{SH}$ & $7.20 \mathrm{E}-06$ & 27 & 30 & 468 & 45.9 & 12.3 \\
\hline
\end{tabular}

Notes:

Color abbreviations: $\mathrm{Y}=$ yellow, $\mathrm{B}=$ brown, $\mathrm{O}=$ orange;

Shape: SH=subhedral, SR=subrounded, E=euhedral, R=rounded. 